\title{
Review \\ Effects of Wildfire on Rockfall Occurrence: A Review through Actual Cases in Spain
}

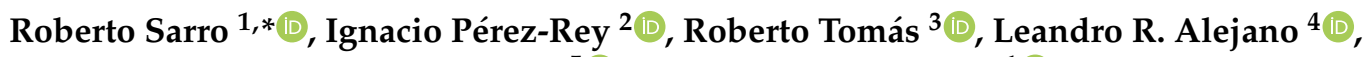 \\ Luis Enrique Hernández-Gutiérrez ${ }^{5}$ (D) and Rosa María Mateos ${ }^{1}$ (D) \\ 1 Department of Natural Hazards, Geological Survey of Spain (IGME), Ríos Rosas, 23, 28003 Madrid, Spain; \\ rm.mateos@igme.es \\ 2 Geotechnical Laboratory, CEDEX, 28014 Madrid, Spain; ignacio.perez@cedex.es \\ 3 Department of Civil Engineering, University of Alicante, P.O. Box 99, 03080 Alicante, Spain; \\ roberto.tomas@ua.es \\ 4 Department of Natural Resources and Environmental Engineering, University of Vigo, Campus Universitario \\ Lagoas-Marcosende, s/n, 36310 Vigo, Spain; alejano@uvigo.es \\ 5 Regional Service of Studies and Ecological Impacts of the Canary Islands Government, 38001 Tenerife, Spain; \\ geologoluis@gmail.com \\ * Correspondence: r.sarro@igme.es; Tel.: +34-91-349-5917
}

Citation: Sarro, R.; Pérez-Rey, I.;

Tomás, R.; Alejano, L.R.;

Hernández-Gutiérrez, L.E.; Mateos, R.M. Effects of Wildfire on Rockfall Occurrence: A Review through Actual Cases in Spain. Appl. Sci. 2021, 11, 2545. https://doi.org/10.3390/ app11062545

Academic Editor: Edoardo Rotigliano

Received: 5 February 2021

Accepted: 9 March 2021

Published: 12 March 2021

Publisher's Note: MDPI stays neutral with regard to jurisdictional claims in published maps and institutional affiliations.

Copyright: (c) 2021 by the authors. Licensee MDPI, Basel, Switzerland. This article is an open access article distributed under the terms and conditions of the Creative Commons Attribution (CC BY) license (https:// creativecommons.org/licenses/by/ $4.0 /)$.
Featured Application: This review contribute to understand the mechanisms underlying the observed rockfall activity during and after a wildfire, to advance in the solutions and methods to address the study of the problem, and to assess the hazard during and after wildfire, and its impact on not only transportation infrastructure and urban areas, but also the population. The results will help the decision makers and emergencies authorities to evaluate the exposure of elements at risk, to define actions to reduce their vulnerability and to identify measures to mitigate damages and social impact.

Abstract: Understanding processes and conditions that lead to rockfalls during and after a wildfire in different geological contexts is crucial since this phenomenon is one of the major hazards in mountainous regions across Europe. Spain is one of the European countries with the highest rate of wildfires, and rockfalls cause high economic and social impact, with many fatalities every year. The increase of rockfalls during and after wildfires is connected with the merging of different factors, not only in the detached area but also in the propagation and potentially affected area. When wildfire occurred, many actions take place: changes in the mechanical conditions of the rocks, the loss of protective capacity from vegetation, the effect induced by firefighting activities and/or the impact by the high temperatures in the adopted protective measures. After the wildfire, there is an increase in frequency and intensity of rockfalls in the burned area, causing a major impact of rockfalls on not only road networks and built-up areas but also people living. Additionally, the removal of vegetation by wildfires causes an increase in the risk perception, related not only to detached blocks but also to the general appearance of the rock mass. In this review, the main factors that influence the occurrence of rockfalls after a wildfire are analyzed, and three actual case studies in Spain are presented to support the variety of conclusions obtained.

Keywords: rockfall; wildfire; Spain; modeling; laboratory test; rock mechanics

\section{Introduction}

Wildfires are very frequent in semi-arid and arid climates, particularly during the summer season, where high temperatures, strong winds, and scarcity of precipitation converge. During fires, the temperature can reach over $1000{ }^{\circ} \mathrm{C}$, causing important physical/chemical effects on the soil and rocky substratum [1]. According to the "Forest Fires in Europe, Middle East and North Africa 2019"report, Spain, Portugal and Poland are the 
European countries with the highest number of fires [2]. In the last fifty years, almost 600,000 wildfires were recorded in Spain, affecting about 7.5 Mha, being the $1990 \mathrm{~s}$ the decade with the highest number, with an average of 19,000 fires per year, and an average of 160,000 ha burnt per year. During the last years, the number of fires and the area burned in Spain has decreased. However, the occurrence of large wildfires (affected area $>500 \mathrm{ha}$ ) remains high [3]. Trends in global wildfire activity are changing dangerously, as climatic conditions due to global warming clearly influence the frequency, severity, and extent of wildfires $[4,5]$.

In addition to the environmental effects, wildfires increase the frequency of landslides, and specifically debris flows [6-8] and rockfalls [9]. These post-fire processes enhance the risk posed to infrastructures and people within the burned area. Several studies during the past decade analyzed the susceptibility to debris flows in burned watersheds [10-14]. After a wildfire, there is an alteration of the hydrological and soil conditions by changing the evapotranspiration and infiltration rates, which increases the probability of occurrence of debris flow [15]. These rapid slope-movements can be very dangerous, capable of causing significant damage and fatalities in a single event $[12,16]$.

In the case of rockfalls, there is a lack of exhaustive research on the effects of wildfires. Rockfalls are dangerous phenomena due to high kinetic energy related to the velocity of the falling bocks. This often explains the difficulty of taking fast-enough and effective actions and of designing appropriate protection and mitigation measures [17,18]. After detachment, boulders may move by falling, bouncing, rolling, and sliding. A single block can be fragmented into different boulders during its impact with ground and/or trees. When the block loses enough kinetic energy, it stops reaching its final stable position [19-21]. Understanding the conditions leading to the occurrence of rockfalls during and after a wildfire in different geological contexts is crucial [22], as rockfalls are very frequent in mountain ranges, coastal cliffs and slope cuts.

There are some studies in the scientific literature that reported the increase in rockfallactivity during and after wildfires [9,23-25]. This occurs by the confluence of rock fragmentation by high temperatures, changes in the rock mechanical conditions, and loss in the protective capacity of vegetation. In granular soils, chemical-mineralogical variations take place: dehydration, dihydroxylation, oxidation, etc., while in rocks, mechanical effects by thermal expansion occur [26]. Furthermore, fires increase the erosional processes in the slope, modifying the original topography $[27,28]$, which can significantly change the rockfall trajectories [29-33].

Spain is the second-highest country in Europe, a mountainous country with an average altitude of over $600 \mathrm{~m}$. In this context, landslides are the second most important geohazard (after flooding) regarding damage [34]. In Spain, around 4 million people live in areas susceptible to landslides, which cause annual economic losses of over $160 \mathrm{M} €$ [35]. In the particular case of Spain, the consequences of fires in increasing the rockfall hazard could be of great interest, as Spain is one of the European countries with the highest rate of wildfires [36] and rockfalls are very common, causing great economic and social impacts with several fatalities every year [35].

Wildfires cause great social impacts, such as home loss, property damage, the number of residents evacuated and severe ecological effects. When wildfires occur in mountainous areas, the loss of vegetation exposes the rock and social awareness increases.

In this work, the review of the effect of wildfires on rockfall occurrence is divided into three parts (Figure 1): (i) the detached zone or source area; (ii) the propagation rockfall area, and (iii) the affected zone, where the majority of the boulders and fragments stops. Regarding the source areas, we present the effects of wildfires on the rock mass and its properties: thermal weathering and erosion, degradation of rocks, crack initiation and strength damage. The propagation area comprises the loss of vegetation by the fire and their consequences on the slope. It is difficult to predict when the protective function of a forest against rockfalls will be effective again. These long-term changes in the slope parameters in burned areas have a significant effect on rockfall-runout. 


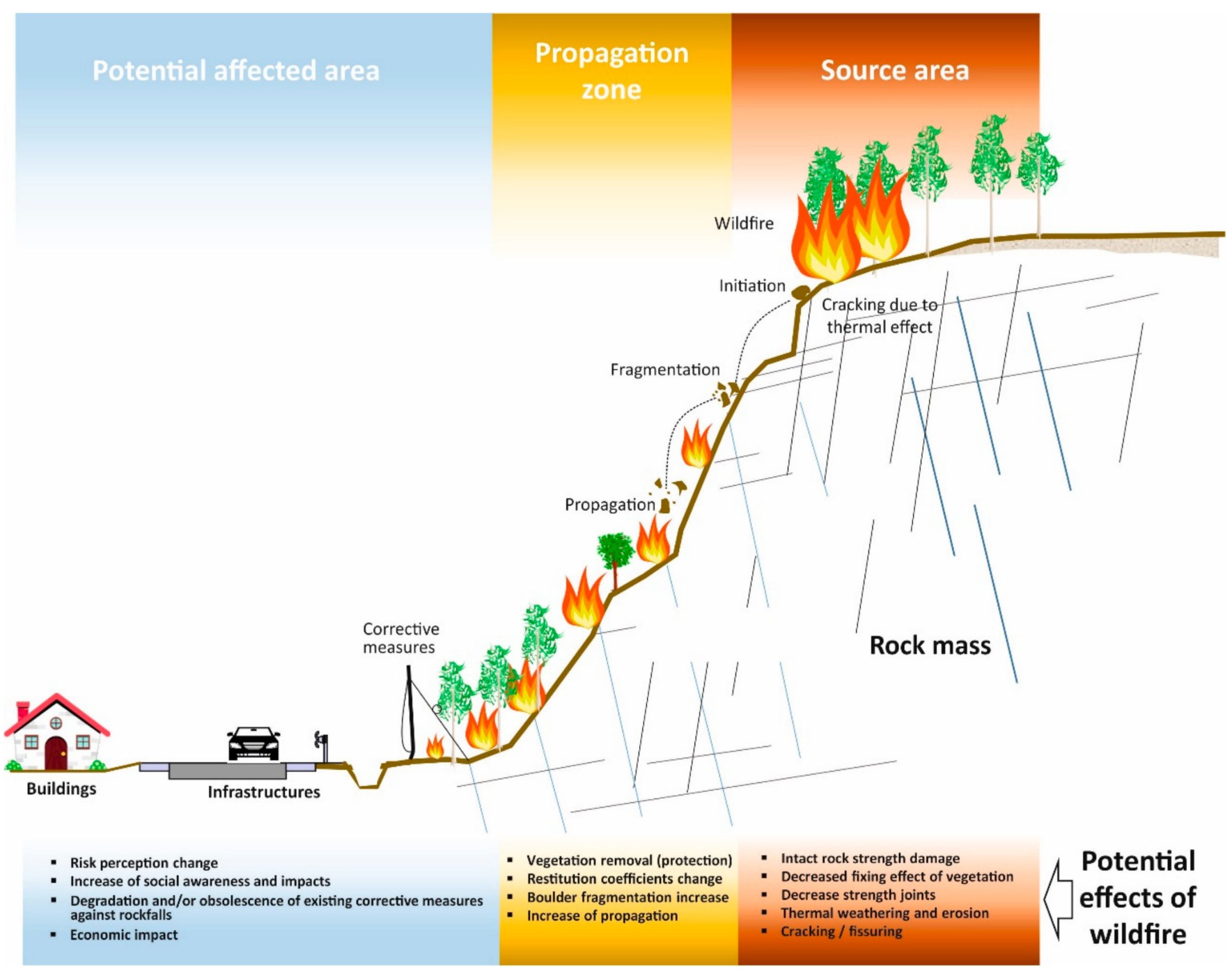

Figure 1. Diagram of potential wildfire effects on rockfall occurrence that frames the structure of this work.

Rockfall modeling has proven to be a very useful tool to predict and perform rockfall hazard simulations from a quantitative point of view before and after wildfires [37]. Thanks to the modeling, it is possible to determine the runout distance of falling rock blocks, computing the rockfall trajectories and estimating the kinematic behavior of the boulders, which is useful information to assess rockfall hazards on infrastructures and urban areas [22,38]. When modeling, we must take into account new input parameters as restitution coefficients as well as variations in the original topography. Finally, the affected area claims for the social and economic impacts after wildfires and the consideration of new protective measures against rockfalls.

To support this analysis, some actual cases in Spain were considered: Galicia, the Balearic Islands and the Canary Islands. They represent different geological contexts and allow us to evaluate how the rockfall hazard varied after a wildfire. In the case of Galicia, we show examples of the wildfire effects on rockfall occurrence in the detachment zone and propagation area. In the Balearic Islands case, we also focused on the propagation area, evaluating how the occurrence of rockfall increased after a wildfire. Finally, in the Canary Islands case, we present the impacts on protection elements, as barriers, in the affected area, and which mitigation measurements were proposed against future rockfalls. 


\section{Source Area: Effects of Fires on the Rock Mass}

High temperatures induced by wildfires cause important effects on the rock matrix. The thermal expansion of constituent minerals origins an increase of contact surfaces between them that causes structural changes that modify the strength of the rock [39-41]. Other processes, such as dehydration or decarbonization, can lead to significant physical changes and mechanical properties of rocks $[40,42]$. Thermo-minero-chemical changes also cause polymorphic transformations, melting, and even the disappearance of certain minerals [40,43-45]. These processes are behind the development of new microcracks and the coalescence and enlargement of existing ones that are responsible for the important changes in the physical and mechanical properties of rocks after a fire $[39,41,42,46-49]$ (Figure 2).

The effect of temperature on intact rocks has been widely studied in the laboratory [50-59]. These studies allow evaluating the changes in the chemical, physical and mechanical properties of rocks when heated. Most of the works use regular samples of intact rock heated in an oven by following standard heating curves, which represent the phenomena under study.

The heating curves usually present three main stages: (a) an initial heating ramp, between 1 to $15^{\circ} \mathrm{C} / \mathrm{min}$, is applied from room temperature up to the target temperature, being $5{ }^{\circ} \mathrm{C} / \mathrm{min}$ one of the most commonly used gradients. It is worth mentioning that the target temperature usually ranges between $200{ }^{\circ} \mathrm{C}$ and $1000{ }^{\circ} \mathrm{C}$, according to the temperature range we are interested in this test. This part of the curve represents the initiation of the fire. (b) Once the target temperature has been reached, it is constant during an interval of time that varies from 1 to $24 \mathrm{~h}$, and usually during one hour. This part of the curve represents the duration of the fire. (c) Finally, the cooling process is simulated in different ways [60,61]: on one hand, some authors cool down the samples within the oven up to room temperature to simulate the slow and natural cooling of the rock. On the other hand, the cooling can be performed in a faster way, by introducing the samples into water or even applying liquid-nitrogen to cause a thermal shock that reproduces the action of extinguishing fires with waters. Once the samples have been thermally treated, they are tested following standardized laboratory methods. Physical properties like volume change, density, porosity, P- and S-wave velocities, attenuation and permeability have been widely studied. Mechanical properties, such as uniaxial compressive strength, tensile, flexural, and shear strength of heated samples of rock have also been widely studied. They show a worsening of the properties with the target temperature since strength and elastic characteristics are significantly reduced. Figure 2 shows the changes of normalized uniaxial compressive strength after thermal treatment at different temperatures following the procedure described above for granites (Figure 2a) and limestones (Figure 2b) similar to those existing in the areas of study of Galicia and Balearic Islands. As it can be seen, the general trend shows a gradual decrease of the properties in both types of rock. More specifically, the main changes in granites (Figure 2a) are observed from $500{ }^{\circ} \mathrm{C}$ due to the phase transition temperature from $\alpha$-quartz to $\beta$-quartz at $573{ }^{\circ} \mathrm{C}$. In contrast, in limestones, the changes are noticed from $300{ }^{\circ} \mathrm{C}$ due to dehydration, absorption, and the decomposition of some cement, and between 500 and $700{ }^{\circ} \mathrm{C}$ due to the decomposition of magnesium carbonate and dolomite, being mostly decomposed from $700{ }^{\circ} \mathrm{C}$ [62]. This variation of the strength of the rock matrix can exert an important impact on the degradation and detachment of rock blocks as well as the later fragmentation on rockfalls. 

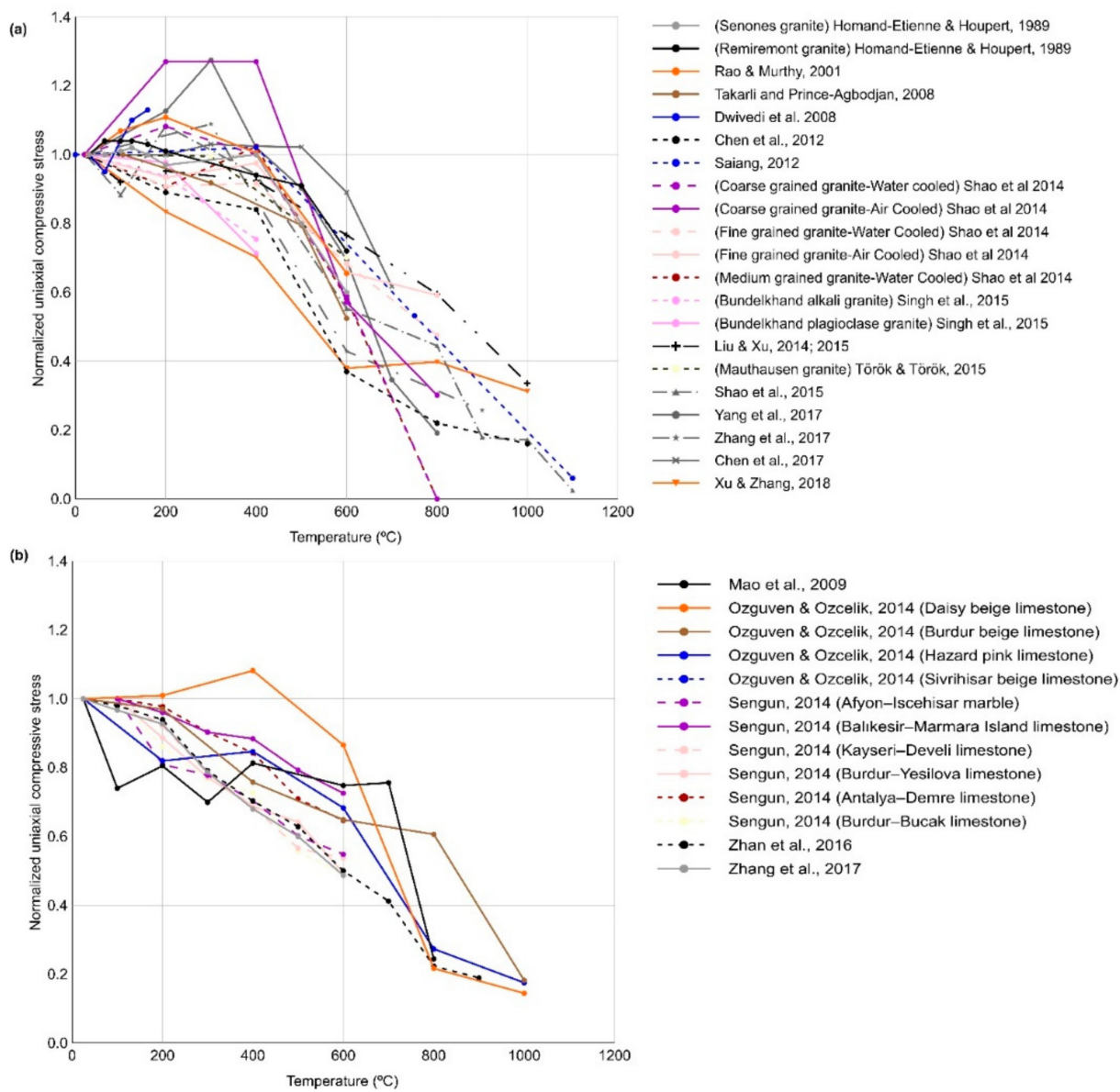

Figure 2. Variation of normalized uniaxial compressive strength of (a) granites and (b) limestones after thermal treatment. The plotted cases were compiled from scientific literature [47,50,53,56,61-75].

The effect of the cooling method is also a factor of importance in rock masses affected by wildfires. Previous studies highlighted that the reduction of strength and elastic characteristics of rocks is greater in rapid-cooled samples than in air-cooled (i.e., slowly cooled) samples, growing crack density due to sudden thermal shock $[49,55,61,76]$.

The effect of temperature on the shear strength of joints has been scarcely studied. Some studies were focused on the evaluation of the shear strength of discontinuities that were subjected to thermal treatments at different temperatures (up to $800^{\circ} \mathrm{C}$ ) by means of a direct shear test [77-80]. These results showed a gradual decline of the shear strength-peak as the temperature increased under normal loading conditions. However, this thermal effect gradually became more reduced as the normal stress increased.

Wildfires mainly affect rock masses, expanding the outer parts, causing internal stresses that exceed the tensile strength of the rock-forming fractures (Figure 3a,b). These fractures are more or less parallel to the surface or influenced by various lines of weakness, such as stratification, "blind joints", rift, veins, and schistosity yielding fragments of many shapes and sizes $[81,82]$. Thus, the presence of matrix in detritic rocks causes a dampening effect of mineral crystal dilations; however, in massive rocks, the absence of matrix and the greater packing of the crystals increase the efforts between them as they dilate, and cracking occurs (Figure 4). Considering massive rocks with similar porosities and mineral packing, those of carbonate composition are less sensitive to the action of fire than those of siliceous composition [26]. 


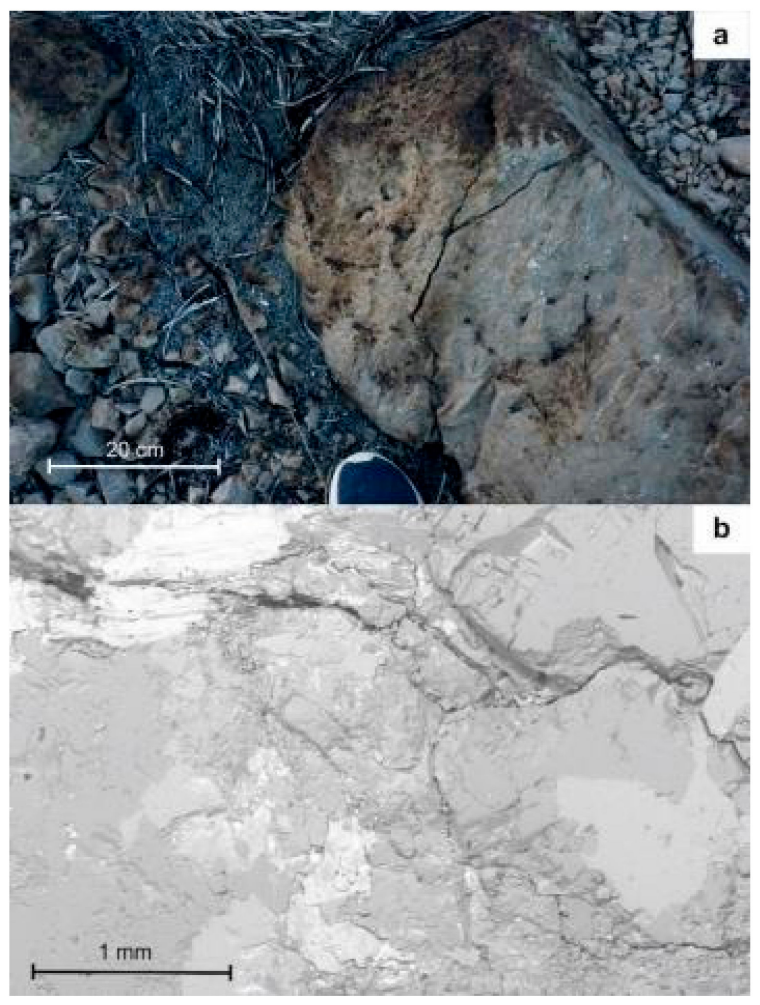

Figure 3. (a) Fractures appearing on a limestone boulder (35 cm across) affected by a forest fire in the Foncalent mountain range located on a dry arid region of Alicante, SE Spain, with a low thermal load. (b) Scanning electron microscope image of microcracks affecting a granite specimen from near Vila Real, N Portugal heated in the laboratory up to $600{ }^{\circ} \mathrm{C}$ and cooled by immersion in water in the Laboratory of Rock Mechanics of the University of Alicante.

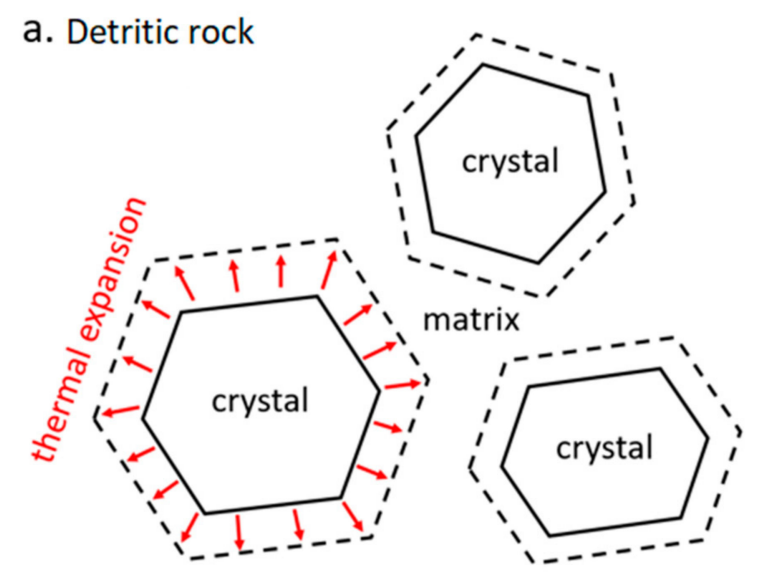

b. Massive rock

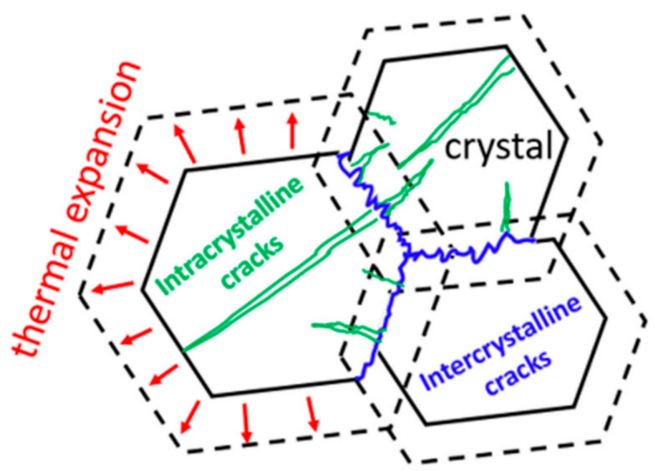

Figure 4. Effects produced by thermal expansion in detritic rocks (a) and massive rocks (b).

\section{Propagation Zone: Changes on the Slope}

Wildfires usually cause the removal of vegetation coverage and the modification of the slope/soil properties. Subsequently, key factors for slope stability can be strongly modified.

\subsection{Removal of Vegetation}

Forests and undergrowth act as natural barriers for protection against rockfalls since they can significantly reduce the runout of rockfalls [83] and provide stability [23]. Vegetation not only decreases the intensity of rockfalls, reducing the energy and the velocity of 
the falling boulders but also reduces their frequency (Figure 5) [84,85]. The distribution and types of trees on the slope influence this protective effect. As the diameter at breast height $(\mathrm{DBH})$ of the trees increases, the capacity of retention of blocks is greater [86,87]. Moreover, the role of roots is also extremely important in soil retention. As a result, rockfall hazards at a forested slope should be analyzed by focusing on both forest characteristics and rockfall dynamics [88].
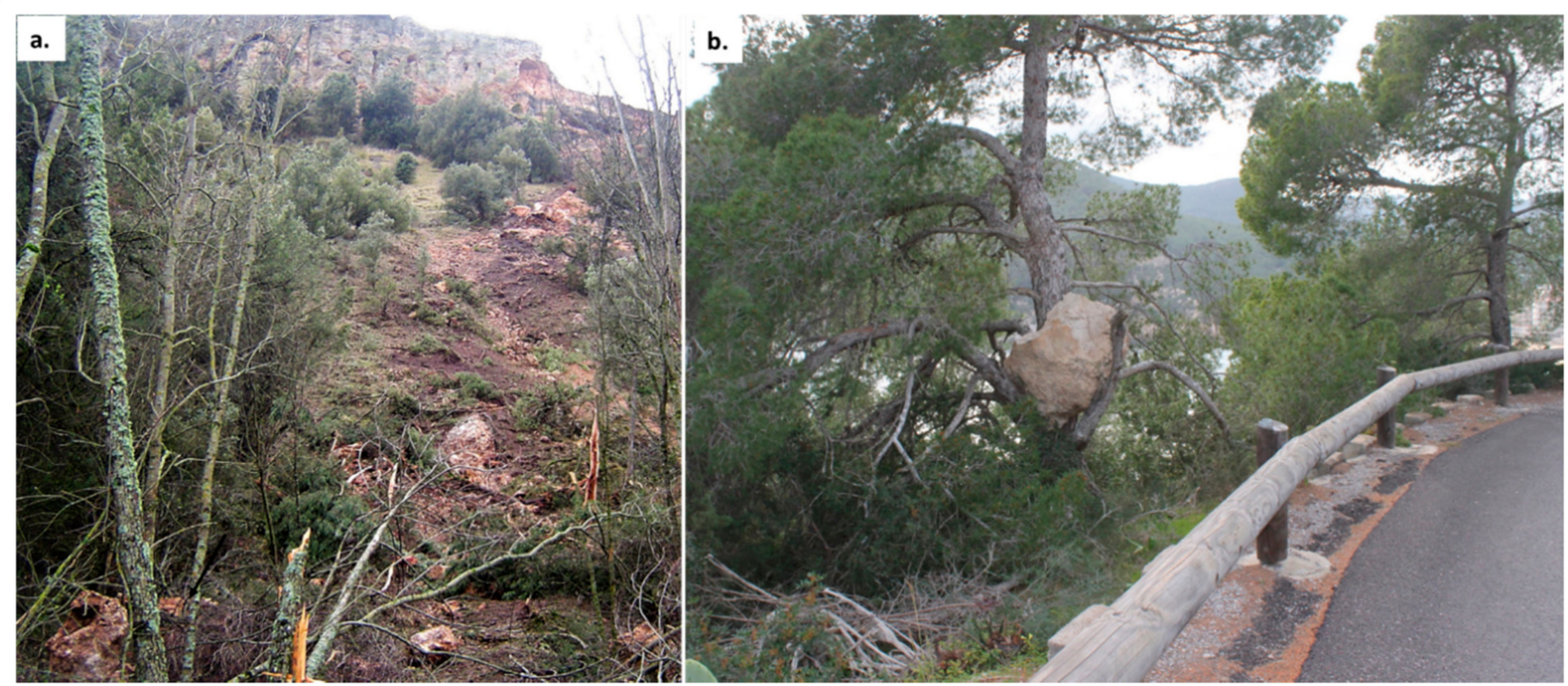

Figure 5. Examples of the protective effect of forests against rockfalls; (a) rockfall in Covarrubias (Burgos), where trees reduced the velocity and the rebound heights of the falling rocks, and (b) rockfall boulder "hanging" from pine in Cala Sant Vincent (Ibiza).

When a forest fire occurs, the natural defense of the vegetation is lost. Wildfires cause damage from the tree crown to the roots, and shrubs use to be completely burned. Moreover, the burned roots in the rock joints accelerate physical weathering processes. However, the effects of the wildfire on the vegetation depend on the intensity and duration of the fire. The total recovery of the environment after a fire can take from a few years to several decades, depending on many factors and, specifically, on the climatic conditions [14]. The critical role of climate change combined with high severity fire is demonstrated, as well as a slower capacity of vegetation recovery after wildfires [89].

\subsection{Modification of The Slope Properties: The Modeling Parameters}

Several computer programs have been designed to model rockfall trajectories as one of the most effective tools for the analysis and assessment of rockfall risk. Thanks to modeling, it is possible to determine the rockfall trajectories and to estimate the kinematic behavior of the boulders in order to improve the protection of endangered urban areas, road networks and infrastructure.

Taking into account how to calculate the trajectories, rockfall models can be categorized into three main groups: empirical models, process-based models and GIS-based models [33]. In addition, simulations can be two-dimensional or three-dimensional. The $2 \mathrm{D}$ models assume that the rockfall occurs in a linear plane and that the trajectory is not affected by the slope surface. In contrast, 3D models are able to simulate the overall movement of the block, including falling, rolling, sliding and bouncing with high accuracy. Finally, rockfalls can be simulated using a probabilistic or deterministic approach. In the probabilistic or stochastic approach, trajectories vary randomly, within predefined ranges according to certain probability distributions (input data). In order to minimize the inevitable uncertainties associated with rockfall simulation, most current models adopt a probabilistic approach [90]. 
Most of the rockfall modeling programs work along user-defined slope profiles and require detailed information on the outcropping materials. Among the input parameters when performing numerical simulations of rockfalls are the rockfall detachment areas, starting velocity of the boulders, a digital terrain model (DTM) and data of the coefficients of dynamic rolling friction, and of normal and tangential energy restitution used to simulate the loss of energy when rolling and at impact points. The most important is the restitution [91-93] and the dynamic friction [33,94] coefficients. Restitution coefficient $(R)$ represents the ratio of pre-impact and post-impact velocity between the boulder and soil, and it is subdivided into tangential (Rt) and normal ( $\mathrm{Rn}$ ) components. These coefficients basically depend on the angle of impact and the properties of the soil [93]. Dynamic friction coefficient determines the force in the opposite direction of the sliding of the block. The value of the friction coefficient depends on the shape and on the characteristics of the slope. Both coefficients quantify the amount of energy lost during the impact of a block over the slope surface. Despite the different techniques and studies developed to evaluate these parameters, the values of the restitution coefficients and friction coefficients are still not standardized.

If the simulation is carried out in a burned area, the effects of the fire must be taken into account. Intense wildfires induce impacts on soils in the short-term: the reduction of vegetation cover, the deposition of ash after the combustion of biomass, the induction of enhancement of water repellency and changes in the structure and soil components [95]. Nevertheless, the literature on the modeling of rockfalls shows very few studies that take into account how the restitution coefficients and the dynamic friction coefficient change after wildfires. Sabatakakis et al. [91] estimated the new values of the restitution coefficients in five cases in western Greece. According to these authors, Restitution coefficient values can be increased after the fire.

\subsection{The Subsequent Increase of Rockfall Occurrence}

Rockfalls are the result of the combination of geological, geomorphological and climatic factors. Usually, the rockfall inventories only record events affecting dwellings, roads or infrastructures. After a wildfire, not only new detachment areas appear, but also the rockfall-runout is longer, and new infrastructures can be reached.

Regarding geological characteristics, the discontinuities of the rock mass play a fundamental role. The characterization of discontinuity sets can be carried out according to geomechanical and geometric criteria. Within the geomechanical characteristics, the number of sets of discontinuities that affect the rock mass, as well as the nature of its filling (if any) and the presence or absence of water, stand out first [96]. During a wildfire, these conditions are altered. Furthermore, there is a degradation in the rock matrix properties reducing the rock strength and increasing the fracturing of blocks and the potential to disaggregation of the initial rock mass and breakage of the blocks during the occurrence of rockfall processes (i.e., increase fragmentation potential).

The increase of rockfall after a wildfire is not only associated with the effects on the rock mass but also with the loss of vegetation. Dorren et al. [88] explained that trees reduce the energy of the boulders mainly in three ways: rotation and translation over the roots, deformation by their hit in the tree stem, and penetration of the rock in the impact. With regard to these considerations, there is a relation between the type of forest (i.e., DBH or density) and its capacity to hold back boulders of a specific size. Some studies $[87,97]$ suggest that a forest should account for one-third of the size boulders with the mean DBH, producing a reduction of rockfall velocity in $26 \%$ on average and the maximum rebound height by $75 \%$ on average.

\section{The Affected Area: Changes to the Potential Risk}

Rockfalls are one of the main threats to firefighter work practices. Additionally, the measures installed to retain the detached blocks can be seriously damaged during the fire 
or can become obsolete under the new conditions. As a result, wildfire disturbances can have an adverse effect on the potential risk and cause important socio-economic impacts.

\subsection{Firefighting and Rockfalls}

Wildfire fighting is a hazardous activity. Despite the fact that many studies are focused on firefighter's exposure to gases or temperature during a fire extinction, little is known regarding the exposure of firefighters to rockfalls. The main statistic to evaluate the effect of rockfalls in firefighting activities is the number of fatalities. In the USA, data provided by the US Fire Administration (USFA) show a general upward trend in deaths of firefighters. In the nine-year period January 2000 to October 2019, there were 99 fatal injuries in wildland fires. Regarding the cause of fatal injury, $32.3 \%$ of the fatalities were caught or trapped. $23.2 \%$ of the fatalities were due to collision of the vehicle and $20.2 \%$ of them by stress/overexertion. Nevertheless, the fourth cause of fatalities was related to struck by elements, such as rocks or trees $(16.2 \%)$. Almost $70 \%$ of these deaths occurred during the extinction of the wildfire [98].

In Spain, there is a lack of information about firefighter fatalities; the official information records 3 deaths caused by rockfall impacts during the last 10 years [99]. Additionally, we had an interview with a senior official of the operational services of the Consorcio Provincial de Bomberos de Alicante (Spain), who informed us about some actions developed during firefighting that can trigger rockfalls, which are also contained in some Spanish official fire extinction guidelines [100-102]. The main causes are: (a) the destabilization of boulders due to the stretching of the hose lines; (b) the movement of firefighting equipment (e.g., fire trucks) and personnel near slope edges or on slopes; (c) the impact of water projection on slopes and cliffs by hoses or aerial forest firefighting means.

\subsection{Degradation and Obsolescence of Protective Measures}

In many cases, protection elements are installed to deal with rockfalls: bolt fixing, cable netting or shotcrete are commonly used. In those places in which it is necessary to protect critical elements, such as roads or buildings, the use of barriers is also very common. Rockfall barriers are designed (inclination, height, energy absorption capacity and location), taking into account boulder characteristics, such as energy, bounce height, runout, etc. [103]. The role of these barriers is to hold back the boulders during their trajectories along the slope, able to become deformed, transmitting the energy of the falling boulders to the slope throughout a system of cables, anchors and energy dissipators [104-106].

However, when a fire occurs, these protective measures can be seriously affected by the high temperatures (Figure $6 \mathrm{~b}$ ). One of the main effects of wildfire on rockfall protection barriers is the degradation of the cables and energy dissipators, changing their properties of friction/tightening with cable ties (Figure 6a). In this case, cables, energy dissipators and nets would be replaced. High temperatures can also destroy nets and bolts, which become brittle and weak depending on the composition of these elements and the temperature reached during the fire.

On the other hand, after a fire, rockfall barriers may become inoperative. The design of the rockfall barrier usually takes into account the energy level calculated from rockfall trajectory simulations and the results obtained from full-scale tests and the support of standardized prescription. This approach already has a large number of uncertainties due to the input data to carry out the rockfall simulation being often difficult to make accurate identification/measurements, for example, of new source areas or the block size. As a result, heuristic techniques are usually used in the selection of some inputs. In areas where a fire has occurred, these estimates are no longer valid because of the effect that the fire may have had on the source areas and propagation zone, and hence the changes that may occur in the volume of the rock block and the rockfall trajectories [107-109]. 

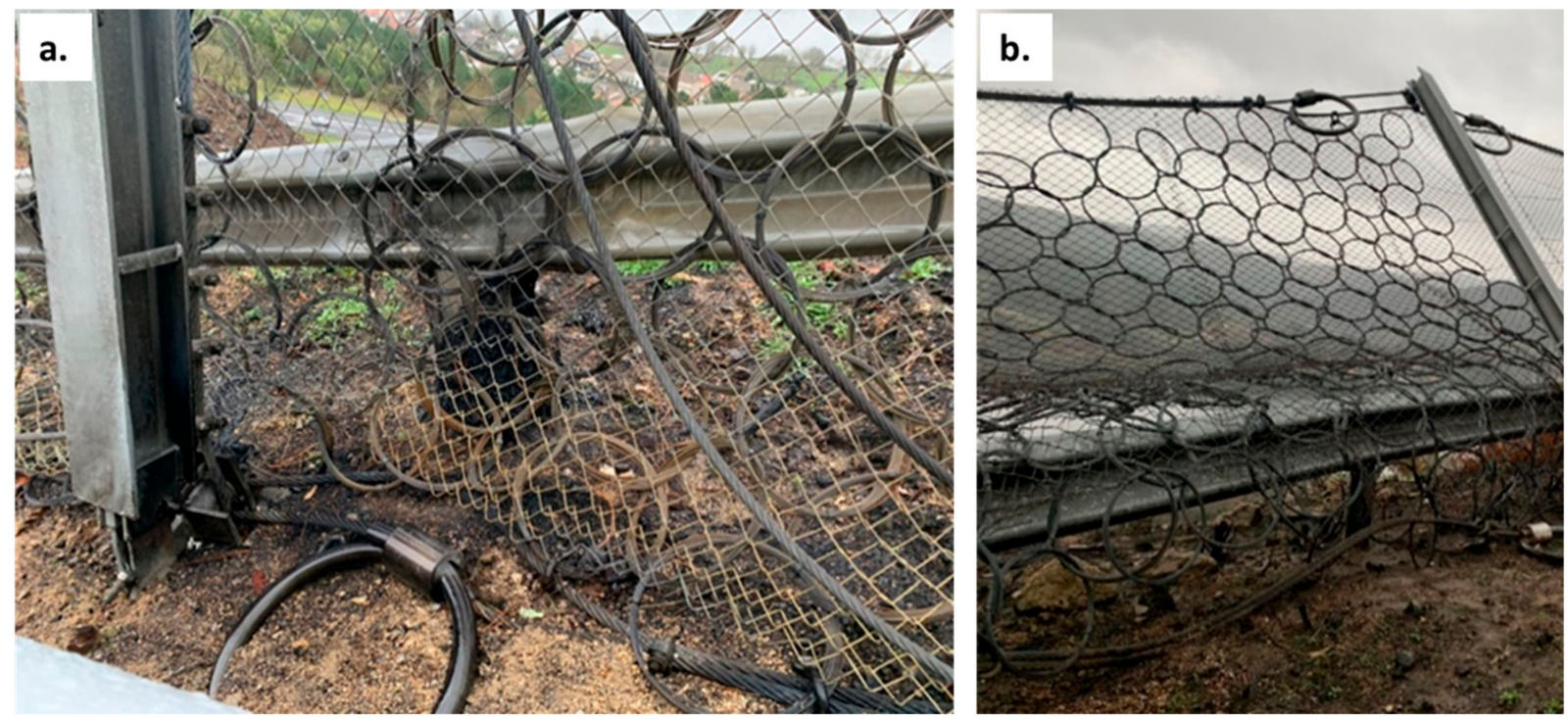

Figure 6. (a) Degradation of the cables and energy dissipators after a wildfire. (b) Dynamic barrier for protection against rockfalls affected by a wildfire.

\subsection{Economic and Social Impacts}

Rockfalls disrupt livelihoods, sometimes causing fatalities and damage to infrastructure or urban areas. The economic impacts from rockfalls can be classified into two categories: (a) direct economic impacts for maintenance works, rehabilitation, etc., and (b) indirect economic impacts, as property damage, injury or fatalities, or environmental impacts [110]. The impact of rockfalls on social systems is generally only addressed by statistics on economic losses related to damaged houses or loss of infrastructure or investment in protective measures against it. There are no references to social impact measures beyond economic loss assessments [35]. The perception of risk is one of the main factors conditioning the behavior of people and, therefore, has a decisive impact on the capacity of the community for mitigation, protection and recovery [111]. Perceptions of rockfall hazards are influenced by the ways in which the risk is analyzed, assessed and managed. Fluent communication and appropriate information to the citizens are essential.

Wildfires cause a social impact by themselves, increasing the sense of vulnerability. When wildfires occur in abrupt or mountainous areas with forest covering rocky massifs prone to falling, this perception is amplified once a fire has been extinguished. The amplification of risk is reflected not only in the adverse effects produced by wildfires but also in the evidence of exposure to other risks, such as rockfalls, of which people were previously unaware. An example of these issues in Spain can be noted in the wildfire that occurred in Ibarrangelu (Basque Country) on 5 April 2020 [112]. The fire affected an area covered by bush and holm oak located above the car park at Laida beach, one of the most frequented beaches in Bizkaia. The impact of the fire was not significant, but therefore, results highlighted that rockfall prone areas were intensively located on the upper and middle of the slope, being visible from the beach. Something similar, although at a smaller scale, was detected in the area of Chandebrito (Pontevedra, Spain) after the occurrence of the forest fire. The development of the corresponding study leading to the installation of the dynamic barrier was motivated, in part, by a general request from the inhabitants of the area, who transmitted their concerns regarding the potential occurrence of rockfalls to the authorities. 


\section{Actual Cases in Spain \\ 5.1. Galicia}

This case study refers to a village located at a foothill in Chandebrito (Pontevedra, Galicia, NW Spain) (Figure 7), where after an intense wildfire, the risk perception significantly increased. This leads to a detailed study on potential rockfall occurrence, concluding the convenience of installing protective measures. The study statistically analyzed the potential detachment of boulders from the rock mass in the conditions encountered after a fire, and it also studies propagation accounting for the loss of natural protection provided by the vegetation by means of rockfall path statistic simulations after a fire. Empirical methods were also applied with the aim of confirming results and better understanding the risk issues at stake.

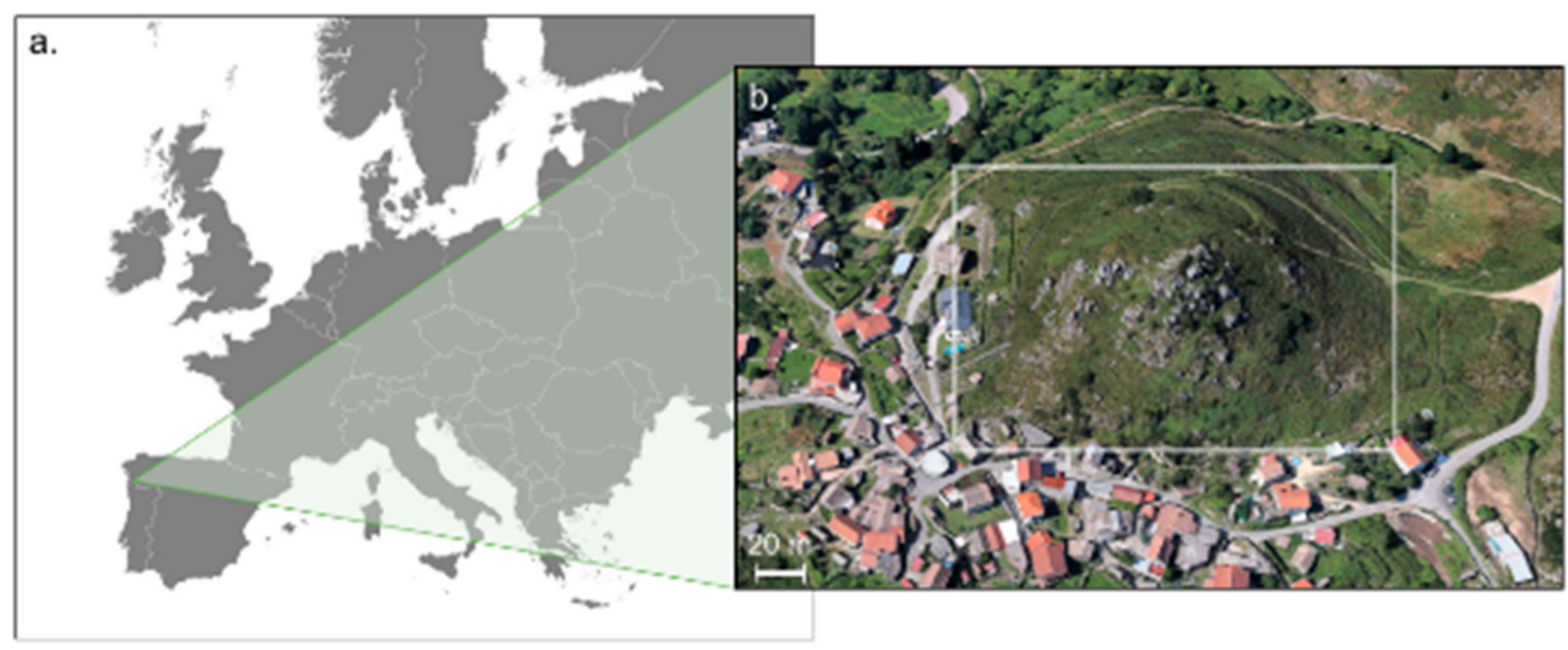

Figure 7. (a) Location of the area of study (Chandebrito, NW Spain); (b) aerial view of the village and hill (indicated by a white contour) from (c) Google Maps.

The area of study is situated next to the small village of Chandebrito in the region of Galicia (Figure 7a). It consists of a granitic hill located at 359 m.a.s.l., where the village of Chandebrito (500 people) is located at the base (Figure $7 \mathrm{~b}$ ) around $50 \mathrm{~m}$ below. The hill is steep with slopes ranging from $30^{\circ}$ to $40^{\circ}$, and maximum values of $50^{\circ}$. High rainfall typical in the area does not contribute to mitigating rockfall risk awareness.

Geologically, the area is part of the Hercynian batholite, where slightly-deformed granites outcrop [113], showing characteristically rounded and boulder-like shapes [114]. Three main joint sets (J1, J2, and J3) were identified during the field survey, and the rock mass was assigned an approximate rock mass rating (RMR) value of 55 . The shrubby hill was affected by a severe wildfire in October 2017 that burned the vegetation (Figure 8a,b). Shortly after the fire, a few new fragmented boulders were identified at the lower part of the slope (Figure 9b). A detailed study, briefly reported in what follows, has been published elsewhere [115].

Input data for the study included (a) basic geotechnical characterization and identification in place of potentially unstable blocks, (b) a detailed 3D point-cloud of the zone and (c) the properties of each lithological unit (tangential and normal resolution parameters and friction coefficients). In the field survey, various potential source areas were located at different points towards the crest of the hill associated with potential sliding and toppling blocks detached from the rock mass and potentially sliding of already detached blocks through erosive processes. This fieldwork permitted to estimate of the probability of occurrence of block instability in $1 / 20$ for a one-year period. 

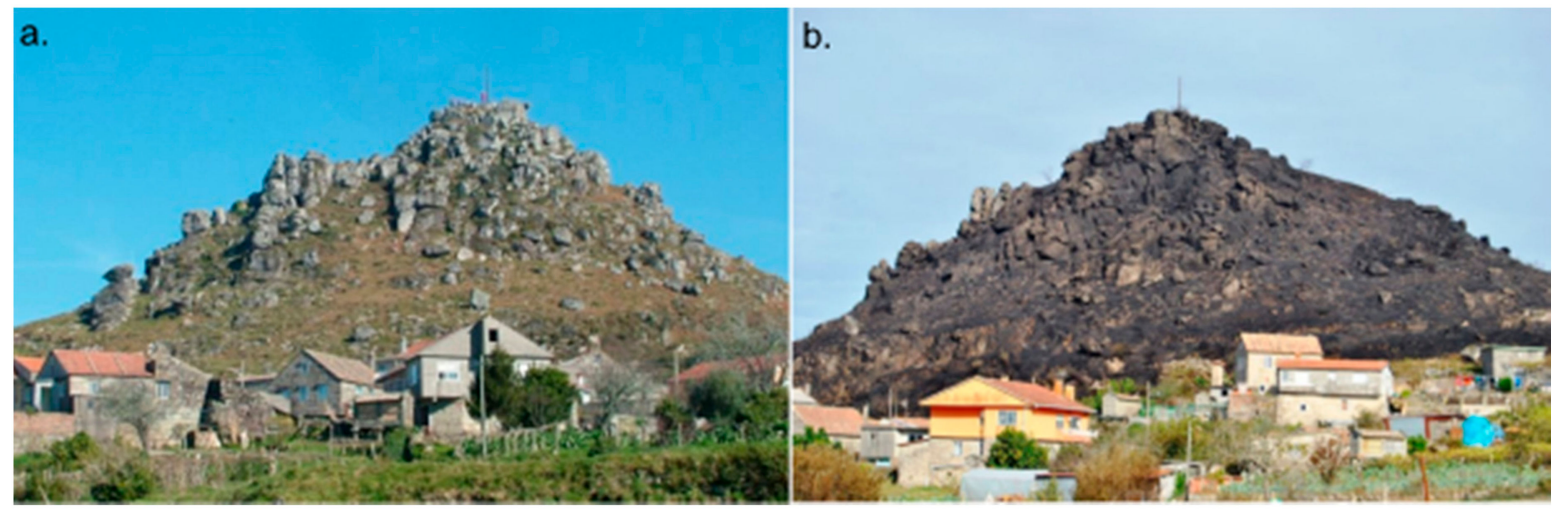

Figure 8. Two views of the study area: (a) before and (b) after the occurrence of the wildfire in 2017 (photos taken by the authors).

Once estimated the probability of block instability, the rockfall risk assessment to the houses below required the analysis of the propagation of potential rockfall trajectories. This can be studied with the help of statistical rockfall simulations, and the program Rocfall [116] was used for this purpose.

Slope geometries are key input data. 3D point clouds offer better topographic resolution helpful in various ways. That is why the authors obtained a 3D point cloud based on LiDAR and standard aerial imagery from an unmanned aerial system (UAS). Classical rock mechanics fieldwork was combined with advanced remote-sensing methods and a semi-automatic classification of the discontinuities following the methodology described in Riquelme et al. [117,118]. This combination permitted accurately quantifying the average volume of rock block in $0.9 \mathrm{~m}^{3}$, one of the relevant input data for the simulations [119]. Additionally, the 3D point cloud was the base for obtaining very accurate maximum dip profiles, starting in the rock block source zones and needed for the simulations. Eventually, 18 eighteen maximum dip profiles were selected from the 3D point cloud with the aim of computing potential rockfall phenomena.

a.

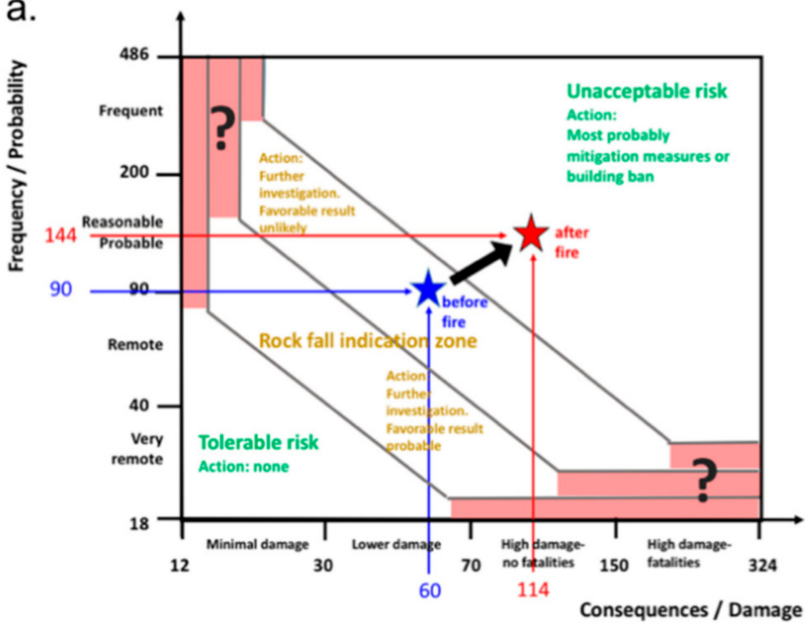

b.

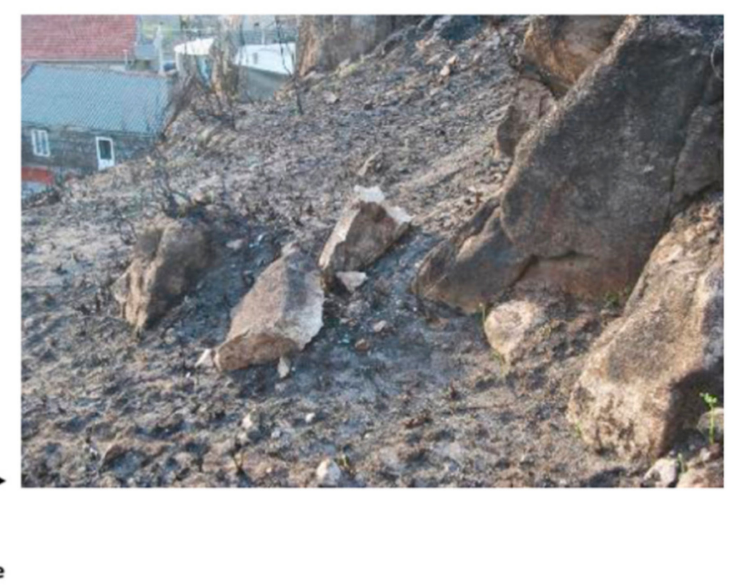

Figure 9. (a) Diagram proposed by Mölk et al. [120] for analyzing frequency/probability vs. consequence/damage. (b) Freshly fragmented block in the lower part of the slope after the fire.

As pointed out above, rockfall propagation tends to be affected by wildfires and loss of vegetation, as it was for the case under scrutiny. Therefore, it was necessary to consider the loss of vegetation in the analysis of the boulders' trajectories. This could be done by updating surface parameters in the rockfall simulations. The wildfire mainly affected the lower zone of the hill (with bushy vegetation, as shown in Figure 8a). Two 
materials were considered concerning coefficients of restitution: bedrock for the upper part of the slope and debris without vegetation for the rest. In Table 1, the corresponding restitution coefficients $\left(k_{n}\right.$ and $\left.k_{s}\right)$ and friction angles $(\phi)$ were selected by the authors based on previous experiences in rockfall modeling in granitic environments [121] and accounting for the effect of fire in both kinds of surfaces.

Table 1. Selected inputs for rockfall analysis with RocFall in Chandebrito [116].

\begin{tabular}{ccccccc}
\hline \multirow{2}{*}{ Material } & \multicolumn{2}{c}{$k_{n}$} & \multicolumn{2}{c}{$k_{s}$} & \multicolumn{2}{c}{$\phi\left(^{\circ}\right)$} \\
\cline { 2 - 6 } & Mean & $\begin{array}{c}\text { Std. } \\
\text { Deviation }\end{array}$ & Mean & $\begin{array}{c}\text { Std. } \\
\text { Deviation }\end{array}$ & Mean & $\begin{array}{c}\text { Std. } \\
\text { Deviation }\end{array}$ \\
\hline $\begin{array}{c}\text { Bedrock after } \\
\text { wildfire } \\
\begin{array}{c}\text { Debris with } \\
\text { burnt vegetation }\end{array}\end{array}$ & 0.35 & 0.15 & 0.85 & 0.05 & 25.0 & 5.00 \\
\hline
\end{tabular}

To carry out the rockfall simulation and based on the 3D point cloud and the location of the rockfall source areas, maximum slope lines were identified (Figure 10a), and the corresponding 18 profiles were obtained in $x-y$ coordinates with a point every $3 \mathrm{~cm}$. Previous studies [122] showed that blocks tend not to deviate more than 5\% from the maximum slope lines, which justifies the use of simpler 2D rockfall models. These profiles were input into RocFall code [116] together with the corresponding parameters of Table 1 and the block size estimated. For illustrative purposes, profile 12 is shown in Figure 10b.

Results provided by the code include end fall-path positions and bounce height for every profile. Around $5.2 \%$ of falling blocks in profile 12 would impact the houses placed on the foot of the slope. This means that in general, 1 out of 20 blocks detached from the central zone would impact the houses below. Note that, whereas in the central profiles (Figure 10a: 5 to 14) a small percentage of rocks (1-5\%) would impact the houses, in the external profiles (Figure 10a: 1-4 and 15-18), the rocks would never attain the buildings below, so protective measures were not needed in these external zones.

Multiplying the above-mentioned probability of block instability $(1 / 20)$ times the propagation probability that a detached block attained the houses $(1 / 20)$, we estimated a probability of accident around $1 / 400$. This is more than twice that typically accepted as suitable for the general public (1/1000), so a panel indicating "entering at your own risk" is typically placed in those areas where the risk is estimated over this threshold. This was a clear indication that some protective measures were in order. Based on the rockfall path models and accounting for the block weight computed and the bounce height (Figure 10b) and kinetic energy of falling blocks provided by the simulation, a dynamic barrier about $2 \mathrm{~m}$ high and $100 \mathrm{~m}$ long able to absorb $500 \mathrm{~kJ}$ impacts was designed and installed in the area to protect the houses.

Complex natural phenomena, such as rockfall, are difficult to analyze, and some estimative assumptions are typically needed, as was the case to achieve the conclusions presented so far. In this sense, it is interesting to compare results with natural observations and other methodologies; if existing, empirical methods tend to be a good choice for this purpose, so they were used to analyze the case from a different perspective. Although other empirical approaches, such as RHRS and ROFRAQ, were tentatively applied $[123,124]$, the most suitable methodology and that was finally selected was the R3S2 approach [120]. It focuses on inhabited valleys in mountainous regions and permits frequency-consequences analysis of scenarios with different types of vegetation (Figure 9a). The application of this method was based on rough estimates on different aspects of the rockfall process that were quantified in place. The application of R3S2 showed significantly different rockfall risk levels before and after the fire. While it was inconclusive for the original situation, recommending further studies; it clearly suggested the need of active measures to protect the village (dynamic barriers) for the conditions encountered after the fire event. It is relevant to mention that indeed R3S2 is probably the only empirical method that considers 
in an explicit way the role of vegetation in the rockfall paths (though this can be accounted for in a not so explicit manner for other approaches), so it could be potentially appropriate to reflect the impact of wildfires on rockfall hazard assessment and mitigation.

Consequently, the traditional approach enhanced by the information derived from the accurate 3D point cloud and combined with rockfall simulations yielded the same conclusion as this empirical approach, which largely improved the reliability of the solution proposed. The risk-awareness of rockfalls in Chandebrito (Pontevedra) was much more evident after the fire and led the population to require the analysis briefly presented. Based on the conclusions of this study and also accounting for the fact that the presence of a pre-Roman hillfort in the site prevented the excavation of the slope, a dynamic barrier was finally selected as the most appropriate solution, so it was projected and installed two years after the wildfire (Figure 10b). The total amount of the performed intervention was near $50 \mathrm{k€}$.

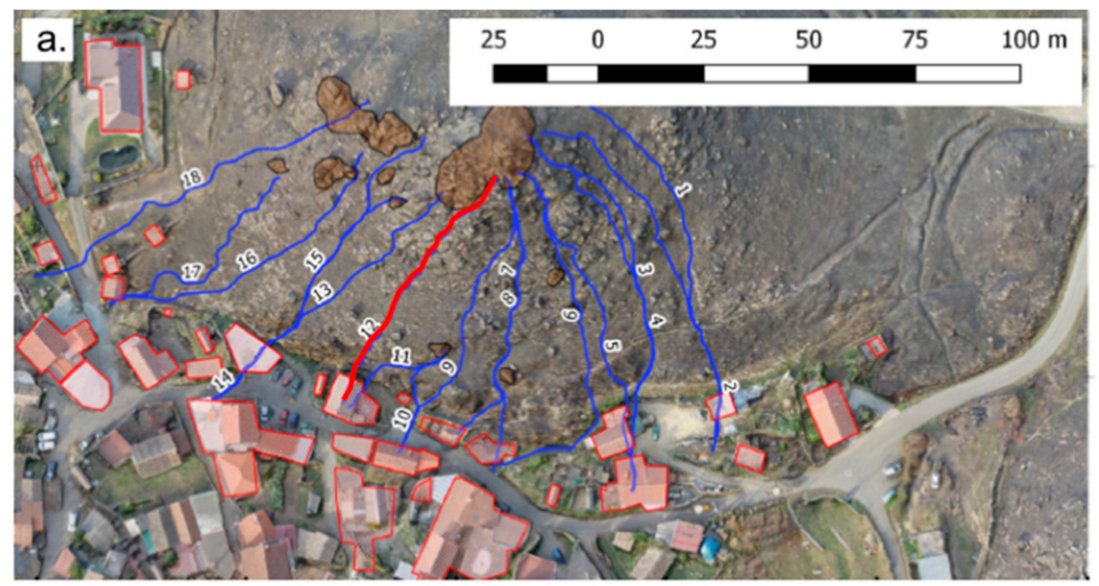

b.

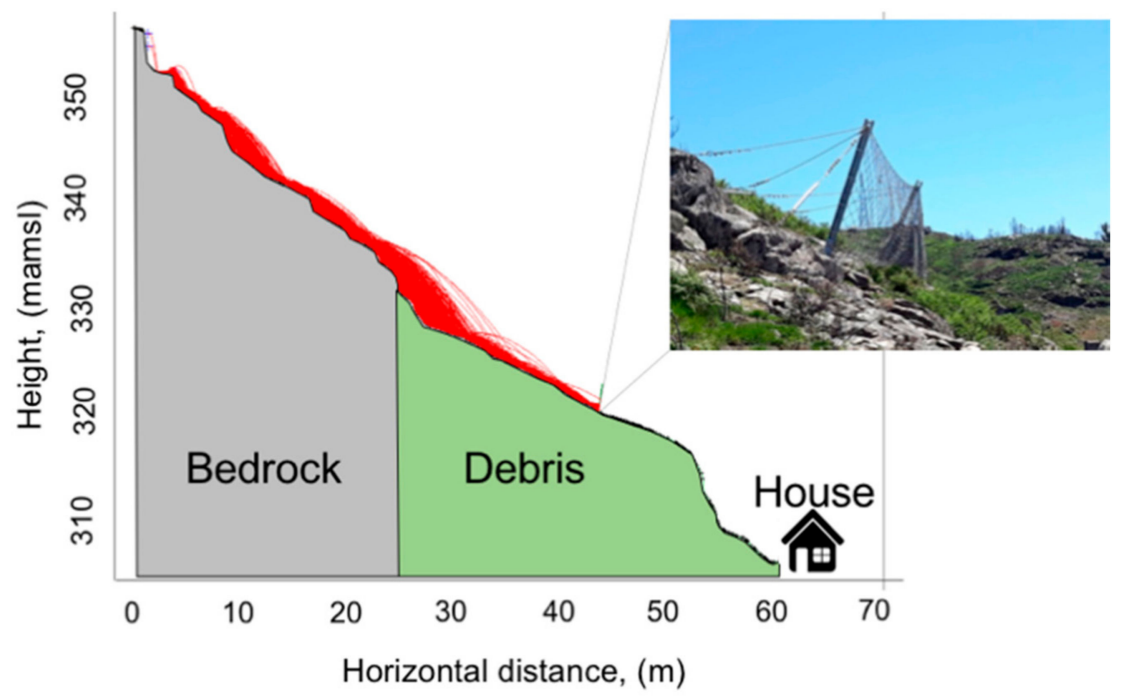

Figure 10. Modeling of rockfall paths for the study in Galicia. (a) Selection of maximum slope trajectories or rockfall-paths based on the 3D point cloud. Profile 12 is highlighted in red color. (b) Geometry of profile 12 input in RocFall code, including different materials and simulation of profile 12 with the designed flexible barrier. A picture of this barrier once installed is also provided.

\subsection{Balearic Islands}

We evaluate the increase of rockfall activity after the wildfire (Figure 11) that took place in Mallorca during the summer of 2013. 

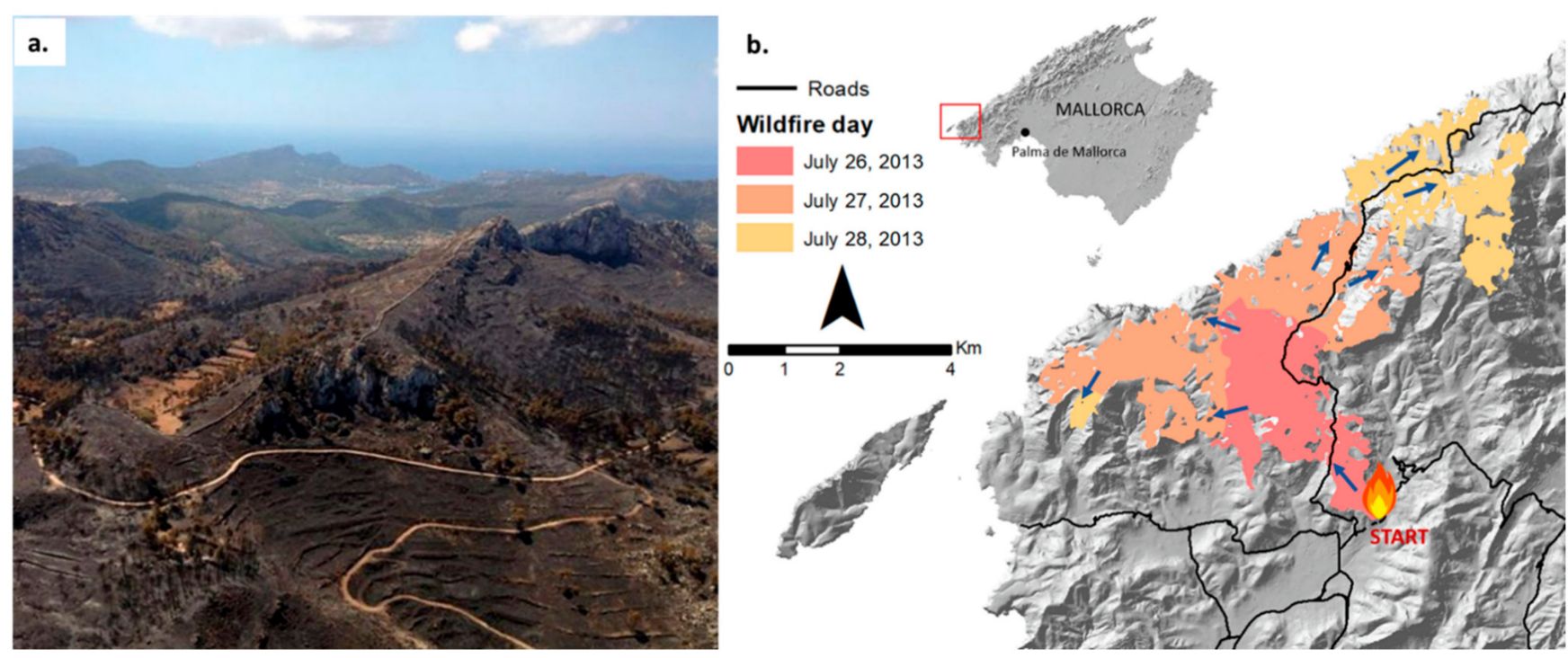

Figure 11. (a) The 2013 forest fire in Mallorca. A total of 2400 hectares were burned in the southwestern part of the Tramuntana range (Photo (C El País). (b) The right map shows the spread of the fire over time.

The Tramuntana range (around $1100 \mathrm{~km}^{2}$ ) forms the backbone of the NW part of the island. It runs for about $90 \mathrm{~km}$, with a maximum width of $15 \mathrm{~km}$, over 20 municipalities. The landscape is marked by agricultural terraces constructed in dry stone to extend farmland. The terraces have also played an important role in preventing damage from soil erosion and very frequent slope movements [125]. Pine and holm oaks forest and a rich shrub layer mainly cover the range.

The Tramuntana range is characterized by a steep topography in high geological complexity with several peaks having an altitude over $1000 \mathrm{~m}$ a.s.l. Hard rocks predominate, especially Jurassic limestone and dolostone, which constitute the framework of the mountains. These conditions determine frequent rockfalls, which have caused significant damage, specifically to the road network $[18,30,126]$.

The Ma-10 road is a strategic road and constitutes the main transportation corridor on the northern face of the Tramuntana range. From the total rockfalls registered in the Ma-10 since 1995, 53\% of them were recorded along the southern section of the road, between Andratx and Valldemossa (40 km long). Moreover, there is a special, hazardous road-section between Andratx and Estellencs (approximately $11 \mathrm{~km}$ ), where vertical, rocky fronts define the slopes, with heights up to $200 \mathrm{~m}$. Because of the high rockfall hazard in this section, the road maintenance service of Mallorca installed numerous protecting measures: retaining walls, mesh systems, braking elements, anchorages, barriers, etc. This southern area suffered a forest fire on 26 July 2013 (Figure 11). High temperatures (up to $40{ }^{\circ} \mathrm{C}$ ), dry conditions and strong winds provided the fatal blend. It was one of the most devastating in the island's history, burning 2400 hectares.

Seven hundred people had to be evacuated in Estellencs as well as some homes in Andratx. The Ma-10 road was cordoned off, mainly because the wire netting for preventing rockfalls at the sides of the road was melted, meaning the safety of drivers cannot be guaranteed. The area severely damaged was the far western part of the Tramuntana range, a natural area of great interest. A total of $95 \%$ of the total burned area has a category of a natural area of special interest and a high-level of protection. The abatement and removal of trees that compromised the safety of pedestrian and vehicle traffic were carried out as a priority.

From the first moment, specialists warned that the fire would affect the slope instability at both sides of the Ma-10 road. The first rains of autumn confirmed this when some rockfalls took place, and many blocks invaded the road. The Road Maintenance Service of Mallorca decided the installation of metal meshes on the slopes to prevent stones, rocks, or 
trees fall on the road. Moreover, dynamic and static rockfall barriers were also installed in those road-sections previously identified as the most dangerous. The cost of the adopted measures along the sections of the road network affected by this wildfire reached $1.5 \mathrm{M} €$ (data from the Road Maintenance Service of Mallorca).

In this case, the effect produced by the loss of vegetation was important. During the spanning period 2009-2017, the rockfall inventory collected by the Road Maintenance Service of Mallorca showed a total of 22 significant rockfalls in the area where the wildfire took place (Figure 12). Before the wildfire in 2013, 7 rockfalls were recorded in the burned section of the road between 2009 and 2013; 4 of them took place in 2010 when the island of Mallorca experienced the coldest and wettest winters of the last 40 years [126]. After the 2013 wildfire, between 2013 and 2017, a considerable increase in rockfalls was observed in the same section; a total of 15 rockfalls, which double the number of events for the pre-fire period (2009-2013). Nevertheless, the number of rockfalls could be higher because some fences were installed along the road after the wildfire. Regarding the intensity of the events, a greater heterogeneity of block-sizes was observed after the wildfire. The volume varied from $0.5 \mathrm{~m}^{3}$ to $20 \mathrm{~m}^{3}$ after the wildfire, while in the previous period, they range between $2 \mathrm{~m}^{3}$ and $10 \mathrm{~m}^{3}$.

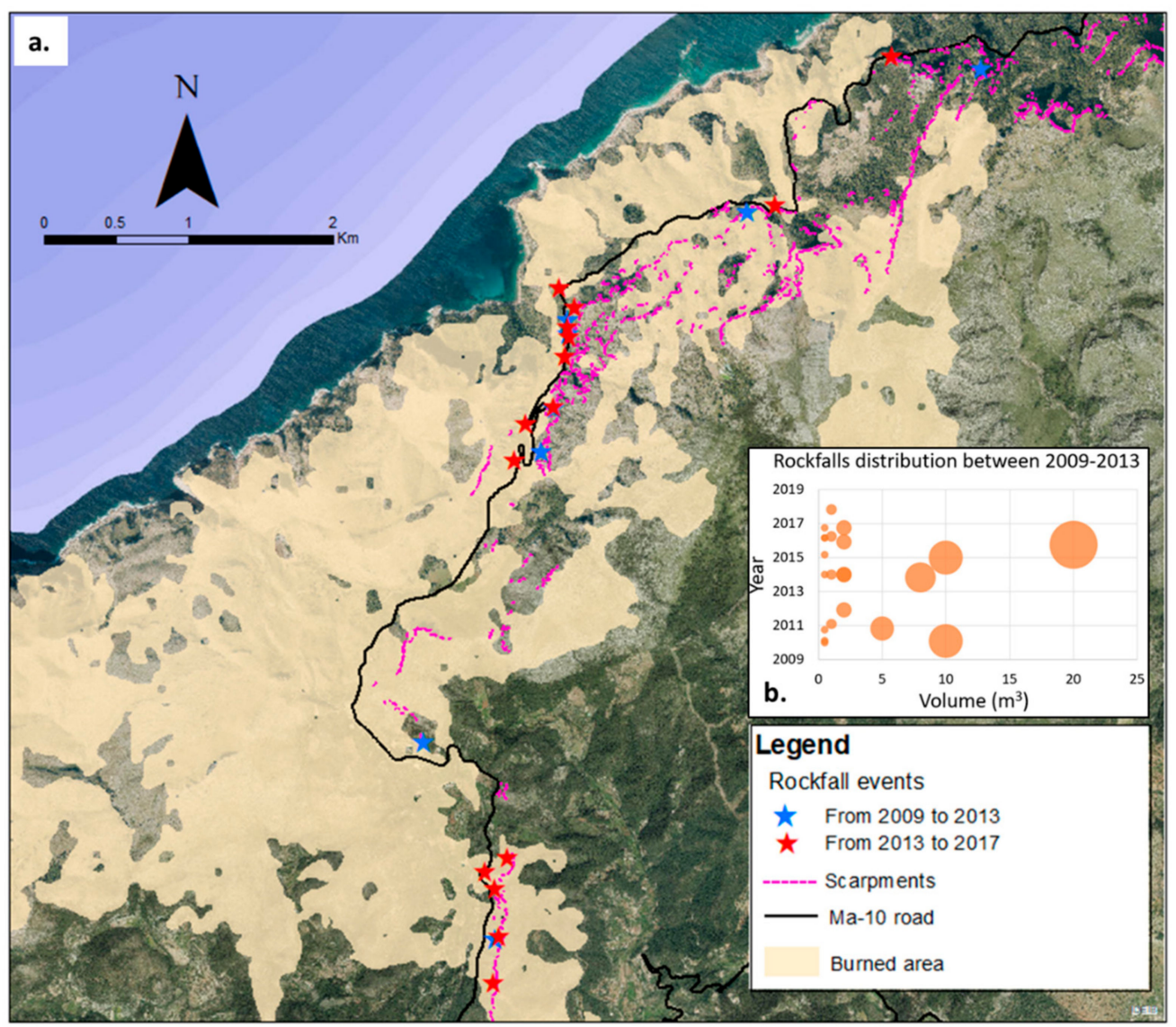

Figure 12. (a) Rockfalls occurred before and after the wildfire in the Tramuntana range (Mallorca) in 2013. We considered the rockfalls in the Ma-10 road reported by the road maintenance service of Mallorca. (b) Rockfall distribution according to the volume of the boulders and considering the year of occurrence.

\subsection{Canary Islands}

Finally, for the Canary Islands test-site, we focus on the affected area (Figure 1), analyzing the protective measurement to establish once the wildfire occurs and what the social and economic consequences may be. Three actual cases of wildfires were studied: Los Realejos (Tenerife), Tejeda-Artenera (Gran Canaria) and La Palma. 
The first case study took place in the municipality of Los Realejos (Tenerife) and affected the TF-5 road, an important coastal infrastructure in the northern part of the island (Figure 13), which runs along the tourist municipalities of Puerto de La Cruz and San Juan de La Rambla. TF-5 is a strategic road with heavy traffic estimated at 29,003 vehicles (Annual average daily traffic, 2019).

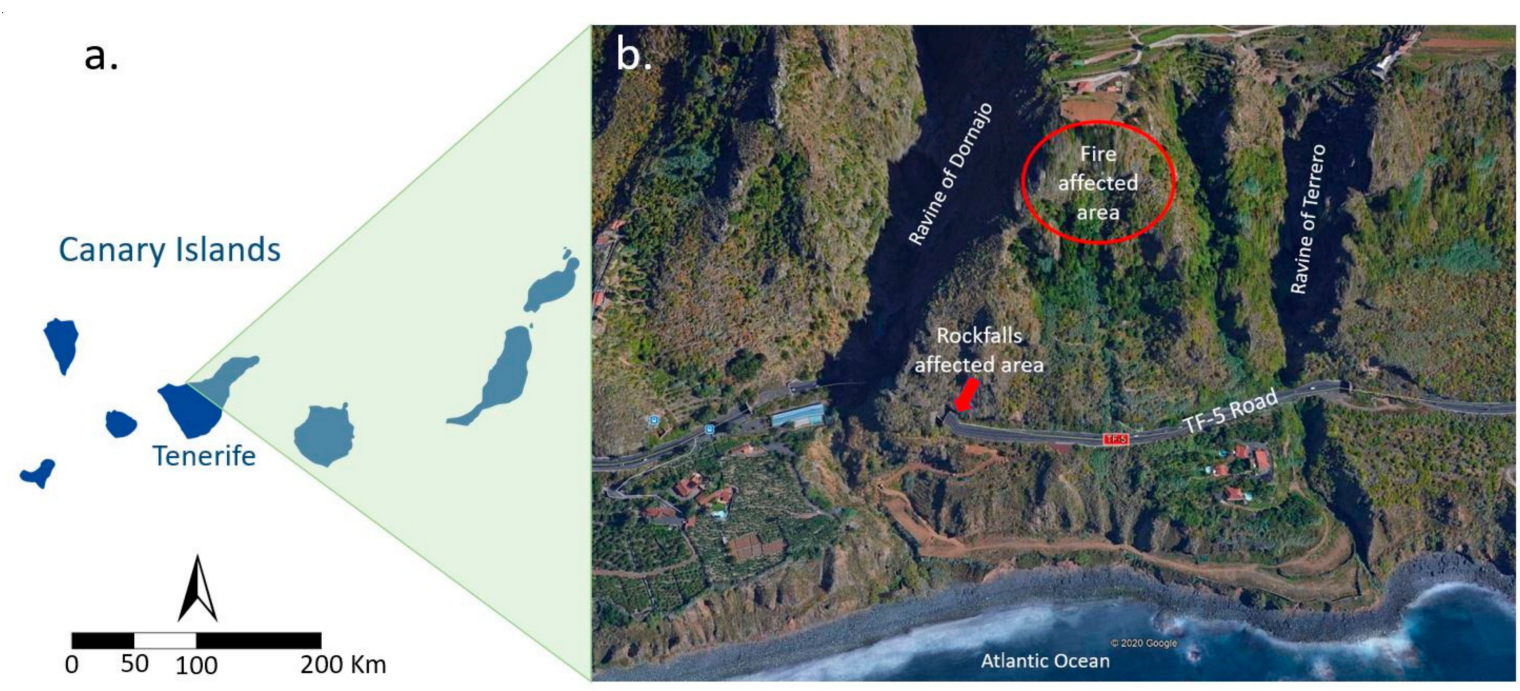

Figure 13. Location of the study area (Los Realejos, Tenerife). The TF-5 road and the fire location are shown (image created using ( Google Earth).

On 23 February 2020, the Canary Islands were affected by a widespread and persistent inrush of suspended dust from the Sahara Desert accompanied by strong winds and high temperatures, which caused numerous fires on Tenerife. One of them, located in Icod El Alto (Los Realejos), triggered a rockfall that affected the road TF-5 at kilometer 43, one of the most important communication routes of the north part of the island. The wildfire occurred at the top of the hill, a steep escarpment of $300 \mathrm{~m}$ in height, and burned bush, scrub, as well as some trees (eucalyptus).

From the geological point of view, the site belongs to the Tigaiga Domain, formed by a vertical accumulation of volcanic deposits slightly inclined towards the sea. A pile of basaltic constitutes the slope, and trachybasaltic lava with pyroclastic material (tuff) interbedded. They are Pleistocene materials with ages ranging from 2.2 to 2.3 Ma [127]. This pile of lava and pyroclasts form a step coastal cliff above the road TF- 5 .

The rockfall occurred three months after the fire (6 and 7 May 2020). On the second day, a vehicle was impacted by a boulder with a size greater than $2 \mathrm{~m}^{3}$ (Figure 14b). Fortunately, there were no fatalities, but the road was cut off for a week. In this case, some additional stabilization and protection measures were installed (Figure 14a): cliff clean-up works; installation of dynamic barriers on the slope; fastening of unstable rock levels through a cable network, and application of shotcrete to the scoriaceous levels to avoid differential erosion. The slope needed the installation of all of these protective measurements over near 10 ha. More specifically, the measurement used for the compact basalt and trachybasalts layers consisted of the installation of $162 \mathrm{~m}^{2}$ of $300 \times 300 \mathrm{~mm}$ galvanized steel cable network panel. The net was placed on the massifs susceptible to mass mobilization and was anchored to the ground by means of Gewi type bolts. Under this cable network, in order to retain the small particles, a triple torsion mesh of galvanized steel with a wire diameter of $2.7 \mathrm{~mm}$ was placed. In addition, three 750-kJ and six 1500-kJ dynamic barriers at different heights of the slope were installed to prevent isolated falling blocks (Figure 14a). Pyroclasts forms were stabilized by applying shotcrete over an area of $1250 \mathrm{~m}^{2}$, with a triple torsion galvanized steel mesh. The total cost of these countermeasures was higher than $125 \mathrm{k} €$. 

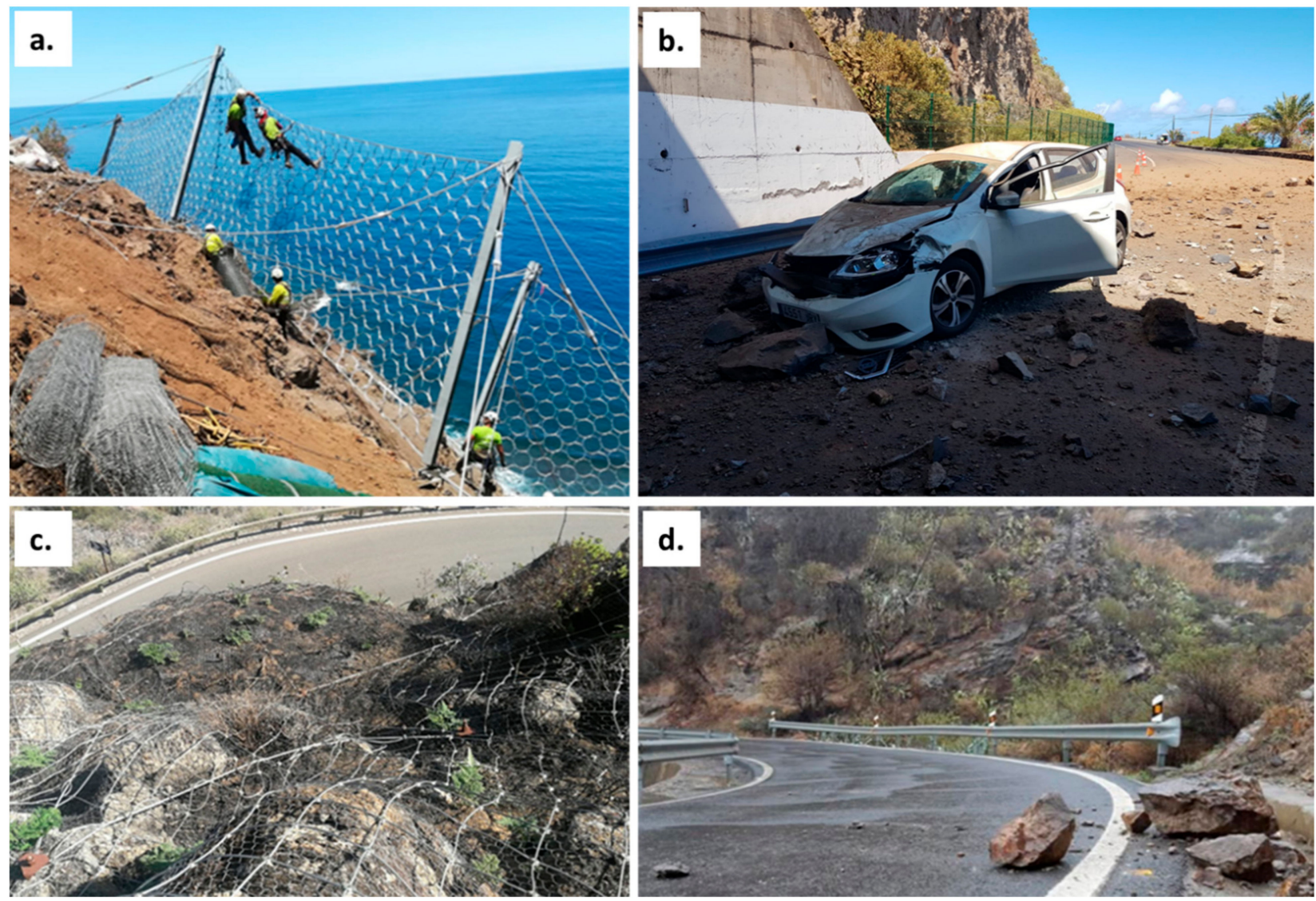

Figure 14. (a) Installation of dynamic barriers on the slope affected by rockfalls in Tenerife test site; (b) vehicle affected by rock impact at km 43 of the TF-5 highway (photos courtesy of V-Traverca). (c) Fence and barrier affected by the wildfire in GC-210 (courtesy of V-Traverca). (d) Rockfall triggered by wildfire in Tejeda (courtesy of Road Service of the Canary Islands).

Despite the installation of these protective measures, rockfalls have continued to occur, although to a lesser extent. For this reason, and in order to guarantee the safety of people, as well as to avoid repeatedly cut off in traffic along TF- 5 road, the regional authorities proposed in 2008 several alternative roads for this section, including the execution of large concrete structures (i.e., viaducts, bridges and false tunnels) with costs higher than $120 \mathrm{M} €$ [128]. In June 2020, the Canary Government put out to public tender the drafting of the project for an amount of $320 \mathrm{k} €$.

The second case in the Canary Islands occurred on 17 August 2019 on the island of Gran Canaria. The fire started near the town of Tejeda and spread to Tamadaba Natural Park, driven by prolonged high temperatures, strong winds and low humidity. According to the authorities' information, over 700 firefighters and 16 aircraft helped to tackle the blaze, with some flames reaching over $50 \mathrm{~m}$ in height. The Copernicus Emergency Mapping Service (CEMS) was activated. The products offered by CEMS were based on comparing pre- and post-event Sentinel satellite images [129]. The Tejeda-Artenara wildfire affected a land surface of $104.5 \mathrm{~km}^{2}, 26.2 \mathrm{~km}^{2}$ of forest, forcing the evacuation of 13,000 inhabitants. In addition, fences and barriers against rockfalls were affected by the high temperatures (Figure 14c), and the road maintenance service noted an increase in the number of rockfalls during the months following the fire. (Figure 14d).

The last case study in the Canary Islands was the wildfire that occurred in August 2016 on the island of La Palma. A great wildfire took place on the southern part of the island, affecting about 5000 hectares, $6.8 \%$ of the total surface of the island, producing an important loss of forest stand. The fire spread quickly through mostly pine and eucalyptus forests. Daytime temperatures in previous days were between $30^{\circ} \mathrm{C}$ and $40^{\circ} \mathrm{C}$. The most affected areas were the municipality of El Paso, where almost 2500 ha of land were burned, 
followed by the municipalities of Fuencaliente (1600 ha) and Mazo (800 ha). The fire forced the evacuation of 2500 people and caused one fatality. Civil Protection Authorities deployed almost 1500 vehicles and 32 water-dumping aircraft to extinguish the fire.

La Palma's volcanic environment is characterized by sequences of volcanic materials with different strengths and a very abrupt landscape. Weaker layers are more susceptible to erosive processes, undermining the base of harder layers and causing blocks to fall, mainly during heavy rains. In vegetated areas burned by wildfires, these instability processes intensified after the 2016 wildfire. In fact, although the regional authorities installed protective measures after the fire, on 2 December 2016, during a period of heavy rains, rockfalls and debris flow in the burned area took place, causing the cutting of the LP-2 road between Las Manchas and Fuencaliente, as well as other roads in the lower part of the island, and burying houses, and infrastructures.

\section{Discussion}

Rockfalls can be triggered by a large variety of natural processes, such as rainfall, cycling thermal stress, seismic activity, etc. [130-133]. Nevertheless, there is a lack of literature about the influence of wildfires on rockfall activity. In this paper, we present a review on this issue through three real cases in Spain.

Climate change and the expansion of human development in furthering the adverse effect of wildfires on lives and property, triggering cascading hazards, including rockfalls. New tools and methods need to be developed to identify and quantify the potential hazards posed by rockfalls in burned areas taking into account the Climate Change scenarios.

Rockfall phenomena are mainly controlled by the source areas and the rockfall runout $[37,134]$. Wildfire can induce significant changes in both. In-deep, new studies focused on understanding how rock mass properties are influenced by wildfires are necessary, and specifically experimental research on the role of high temperatures in the rock-fragmentation and changes in the shear strength of discontinuities.

After a wildfire, the propagation area is also disturbed due to the removal of vegetation. Vegetation is extremely important to protect against rockfall, reducing the velocity and the rebound heights of falling rocks. Therefore, it is necessary to consider the loss of vegetation in the rockfall modeling, mainly the variation of restitution coefficients and friction coefficient. The development of new tools, methodologies represents an essential achievement for the analysis and prevention of rockfalls after a wildfire.

The impact of rockfalls after wildfires, not only on road networks and built-up areas but also on people's hazard-awareness, would need a special analysis. For this purpose, an accurate inventory of rockfalls after wildfires is required to validate simulations as well as to identify new vulnerable elements and check the effectiveness of the defense measures. The results would be highly valuable for experts in dealing with safety and security services and specifically for firefighters.

The three cases reported in the present work demonstrate the close relationship between wildfires and the increase in rockfalls and demand more in-depth studies.

\section{Concluding Remarks}

Fires can induce physical and chemical changes on the rock masses, increasing rockfragmentation and decreasing rock and discontinuity strength.

Rockfall trajectory (runout) is also modified when the vegetation is lost. Forests are extremely important to protect against rockfalls, as trees reduce the velocity and the rebound heights of the falling rocks. In rockfall modeling, the loss of vegetation tends to change the input parameters, in particular the restitution coefficients. Comparing pre- and post-fire simulations would be an effective tool to evaluate the new hazard of the slope.

Specific attention should be paid to match the characteristics of the wildfire (intensity, duration, etc.) with the rockfalls. Mapping fire intensity and burn severity in combination with the rockfall inventory (pre- and post-wildfire) would help to understand their correlation. 
Stabilization and protection measures can be greatly deteriorated by the high temperatures and may lose their functionality. Furthermore, social risk awareness is increased after a wildfire, and people demand new, urgent and expensive protecting measures.

In addition, firefighting actions can increase the rockfall activity. Firefighters and emergency authorities should develop strategies for rockfall risk reduction during wildfires in collaboration with the scientific community. Major efforts on communication must be carried out in areas prone to rockfalls, and wildfires could be a good opportunity for this.

Author Contributions: R.S. (IGME) led and designed the paper. R.M.M. (IGME) and R.S. (IGME) were involved in the analysis of the effects of wildfire on rockfall occurrence in propagation and affected area, and collecting and analyzing data from the Balearic Islands test site. I.P.-R. (CEDEX) and L.R.A. (UV) collaborated in collecting and analyzing data from the Galicia test site. R.T. (UA) helped in collecting data and was involved in the effects of fires on the rock mass and the impact of rockfalls. L.E.H.-G. (GOBCAN) and R.S. (IGME) collaborated in collecting and analyzing data from the Canary Islands test site. All authors wrote and critically revised the manuscript. All authors have read and agreed to the published version of the manuscript.

Funding: This work is funded by the RISKCOAST project (Ref: SOE3/P4/E0868) within the framework of the IV INTERREG SUDOE program.

Institutional Review Board Statement: Not applicable.

Informed Consent Statement: Not applicable.

Data Availability Statement: Not applicable.

Acknowledgments: The authors would like to thank the Consell de Mallorca, who kindly provided the information on the rockfalls events in the Tramontana range, in particular to Joan Rius and D. Raul Aguiló. We also appreciate the contribution of the Canary Government, who kindly provided the information on the rockfalls in the Canary Islands test site. Thanks are extended to Paramassi and V-Traverca companies for granting use of their images of rockfalls triggered by wildfire and fence and barriers affected by wildfire to illustrate this manuscript. Finally, we would like to thank the Consorcio Provincial de Bomberos de Alicante for their support and the information provided.

Conflicts of Interest: The authors declare no conflict of interest.

\section{References}

1. Wotton, B.M.; Gould, J.S.; McCaw, W.L.; Cheney, N.P.; Taylor, S.W. Flame Temperature and Residence Time of Fires in Dry Eucalypt Forest. Int. J. Wildland Fire 2012, 21, 270. [CrossRef]

2. San-Miguel-Ayanz, J.; Durrant, T.; Boca, R.; Maianti, P.; Libertà, G.; Artes Vivancos, T.; Jacome Felix Oom, D.; Branco, A.; De Rigo, D.; Ferrari, D.; et al. Forest Fires in Europe, Middle East and North Africa 2019; EUR 30402 EN; Publications Office of the European Union: Luxembourg, 2020; ISBN 978-92-76-23209-4.

3. Andrade, A.; Bello, J.; Chopo, S.; Elazar, J.M.; Enríquez, E.; Hernández, E.; López-Santalla, A.; Muñoz, A. Los Incendios Forestales en España: Decenio 2006-2015; Ministerio de Agricultura, Pesca y Alimentación; Ministerio de Agricultura, Pesca y Alimentación: Madrid, Spain, 2019; ISBN 003190315.

4. Liu, Y.; Stanturf, J.; Goodrick, S. Trends in Global Wildfire Potential in a Changing Climate. For. Ecol. Manag. 2010, 259, 685-697. [CrossRef]

5. Halofsky, J.E.; Peterson, D.L.; Harvey, B.J. Changing Wildfire, Changing Forests: The Effects of Climate Change on Fire Regimes and Vegetation in the Pacific Northwest, USA. Fire Ecol. 2020, 16, 4. [CrossRef]

6. Cannon, S.H.; Gartner, J.E.; Rupert, M.G.; Michael, J.A.; Rea, A.H.; Parrett, C. Predicting the Probability and Volume of Postwildfire Debris Flows in the Intermountain Western United States. Gsa Bull. 2010, 122, 127-144. [CrossRef]

7. Santi, P.; Cannon, S.; DeGraff, J. 13.16 Wildfire and Landscape Change. In Treatise on Geomorphology; Shroder, J.F., Ed.; Academic Press: San Diego, CA, USA, 2013; pp. 262-287; ISBN 978-0-08-088522-3.

8. Staley, D.M.; Tillery, A.C.; Kean, J.W.; McGuire, L.A.; Pauling, H.E.; Rengers, F.K.; Smith, J.B. Estimating Post-Fire Debris-Flow Hazards Prior to Wildfire Using a Statistical Analysis of Historical Distributions of Fire Severity from Remote Sensing Data. Int. J. Wildland Fire 2018, 27, 595. [CrossRef]

9. De Graff, J.V.; Gallegos, A.J. The Challenge of Improving Identification of Rockfall Hazard after Wildfires. Environ. Eng. Geosci. 2012, 18, 389-397. [CrossRef]

10. Parise, M.; Cannon, S.H. Wildfire Impacts on the Processes That Generate Debris Flows in Burned Watersheds. Nat. Hazards 2012, 61, 217-227. [CrossRef] 
11. Nyman, P.; Sheridan, G.J.; Smith, H.G.; Lane, P.N.J. Evidence of Debris Flow Occurrence after Wildfire in Upland Catchments of South-East Australia. Geomorphology 2011, 125, 383-401. [CrossRef]

12. Cui, Y.; Cheng, D.; Chan, D. Investigation of Post-Fire Debris Flows in Montecito. ISPRS Int. J. Geo Inf. 2019, 8, 5. [CrossRef]

13. Kean, J.W.; Staley, D.M.; Cannon, S.H. In Situ Measurements of Post-Fire Debris Flows in Southern California: Comparisons of the Timing and Magnitude of 24 Debris-Flow Events with Rainfall and Soil Moisture Conditions. J. Geophys. Res. Earth Surf. 2011, 116. [CrossRef]

14. Carabella; Miccadei; Paglia; Sciarra Post-Wildfire Landslide Hazard Assessment: The Case of The 2017 Montagna Del Morrone Fire (Central Apennines, Italy). Geosciences 2019, 9, 175. [CrossRef]

15. Rengers, F.K.; McGuire, L.A.; Oakley, N.S.; Kean, J.W.; Staley, D.M.; Tang, H. Landslides after Wildfire: Initiation, Magnitude, and Mobility. Landslides 2020. [CrossRef]

16. Dowling, C.A.; Santi, P.M. Debris FLows and Their Toll on Human Life: A Global Analysis of Debris-FLow Fatalities from 1950 to 201. Nat. Hazards 2014, 203-227. [CrossRef]

17. Jaccard, C.-J.; Abbruzzese, J.M.; Howald, E.P. An Evaluation of the Performance of Rock Fall Protection Measures and Their Role in Hazard Zoning. Nat. Hazards 2020, 104, 459-491. [CrossRef]

18. Sarro, R.; Mateos, R.M.; García-Moreno, I.; Herrera, G.; Reichenbach, P.; Laín, L.; Paredes, C. The Son Poc Rockfall (Mallorca, Spain) on the 6th of March 2013: 3D Simulation. Landslides 2014, 11, 493-503. [CrossRef]

19. Melzner, S.; Lotter, M.; Linner, M.; Koçiu, A. Regional Analysis of Slope Instability Processes along the Southern Border of the Central Tauern Window (Eastern Alps). Austrian J. Earth Sci. 2015. [CrossRef]

20. Chau, K.T.; Wong, R.H.C.; Wu, J.J. Coefficient of Restitution and Rotational Motions of Rockfall Impacts. Int. J. Rock Mech. Min. Sci. 2002, 39, 69-77. [CrossRef]

21. Losasso, L.; Jaboyedoff, M.; Sdao, F. Potential Rock Fall Source Areas Identification and Rock Fall Propagation in the Province of Potenza Territory Using an Empirically Distributed Approach. Landslides 2017, 14, 1593-1602. [CrossRef]

22. Sarro, R.; Mateos, R.M.; Reichenbach, P.; Aguilera, H.; Riquelme, A.; Hernández-Gutiérrez, L.E.; Martín, A.; Barra, A.; Solari, L.; Monserrat, O.; et al. Geotechnics for Rockfall Assessment in the Volcanic Island of Gran Canaria (Canary Islands, Spain). J. Maps 2020, 16, 605-613. [CrossRef]

23. Gehring, E.; Maringer, J. Disturbance Calls for Disaster: Why Forest Fires Increase Landslides and Rockfall Hazards. RO 2020, 122-125. [CrossRef]

24. Melzner, S.; Shtober-Zisu, N.; Katz, O.; Wittenberg, L. Brief Communication: Post-Wildfire Rockfall Risk in the Eastern Alps. Nat. Hazards Earth Syst. Sci. 2019, 19, 2879-2885. [CrossRef]

25. Calhoun, N.C.; Burns, W.J.; Hay, S.; Staley, D.M.; Kean, J.W. Post-Fire Rockfall and Debris-Flow Hazard Zonation in the Eagle Creek Fire Burn Area, Columbia River Gorge, Oregon: A Tool for Emergency Managers and First Responder. Ph.D. Thesis, Colorado School of Mines, Arthur Lakes Library, Golden, CO, USA, 2019; p. 8.

26. Gomez-Heras, M.; McCabe, S.; Smith, B.J.; Fort, R. Impacts of Fire on Stone-Built Heritage. J. Archit. Conserv. 2009, 15, 47-58. [CrossRef]

27. Rammer, W.; Brauner, M.; Ruprecht, H.; Lexer, M.J. Evaluating the Effects of Forest Management on Rockfall Protection and Timber Production at Slope Scale. Scand. J. For. Res. 2015, 30, 719-731. [CrossRef]

28. Stoffel, M.; Wehrli, A.; Kühne, R.; Dorren, L.K.A.; Perret, S.; Kienholz, H. Assessing the Protective Effect of Mountain Forests against Rockfall Using a 3D Simulation Model. For. Ecol. Manag. 2006, 225, 113-122. [CrossRef]

29. Wyllie, D.C. Calibration of Rock Fall Modeling Parameters. Int. J. Rock Mech. Min. Sci. 2014, 67, 170-180. [CrossRef]

30. Mateos, R.M.; García-Moreno, I.; Reichenbach, P.; Herrera, G.; Sarro, R.; Rius, J.; Aguiló, R.; Fiorucci, F. Calibration and Validation of Rockfall Modelling at Regional Scale: Application along a Roadway in Mallorca (Spain) and Organization of Its Management. Landslides 2016, 13, 751-763. [CrossRef]

31. Sarro, R.; Riquelme, A.; García-Davalillo, J.C.; Mateos, R.M.; Tomás, R.; Pastor, J.L.; Cano, M.; Herrera, G. Rockfall Simulation Based on UAV Photogrammetry Data Obtained during an Emergency Declaration: Application at a Cultural Heritage Site. Rem. Sens. 2018, 10, 1923. [CrossRef]

32. Vick, L.M.; Zimmer, V.; White, C.; Massey, C.; Davies, T. Significance of Substrate Soil Moisture Content for Rockfall Hazard Assessment. Nat. Hazards Earth Syst. Sci. 2019, 19, 1105-1117. [CrossRef]

33. Dorren, L.K.A. A Review of Rockfall Mechanics and Modelling Approaches. Prog. Phys. Geogr. 2003, 27, 69-87. [CrossRef]

34. Corominas, J.; Mateos, R.M.; Remondo, J. Review of landslide occurrence in Spain and its relation to climate. In Slope Safety Preparedness for Impact of Climate Change; Ho, K., Lacasse, S., Picarelli, L., Eds.; CRC Press: Leiden, The Netherlands, 2017; pp. 351-377; ISBN 978-1-315-38778-9.

35. Mateos, R.M.; López-Vinielles, J.; Poyiadji, E.; Tsagkas, D.; Sheehy, M.; Hadjicharalambous, K.; Liscák, P.; Podolski, L.; Laskowicz, I.; Iadanza, C.; et al. Integration of Landslide Hazard into Urban Planning across Europe. Landsc. Urban. Plan. 2020. [CrossRef]

36. Barreal, J.; Jannes, G. Spatial and Temporal Wildfire Decomposition as a Tool for Assessment and Planning of an Efficient Forest Policy in Galicia (Spain). Forests 2020, 11, 811. [CrossRef]

37. Sarro, R. Simulación de Desprendimientos Rocosos Para La Gestión de Emergencias e Infraestructuras. Ph.D. Thesis, Universidad de Alicante, Alicante, Spain, 2019. 
38. Valagussa, A.; Crosta, G.B.; Frattini, P.; Zenoni, S.; Massey, C. Rockfall Runout Simulation Fine-Tuning in Christchurch, New Zealand. In Proceedings of the Engineering Geology for Society and Territory-Volume 2; Lollino, G., Giordan, D., Crosta, G.B., Corominas, J., Azzam, R., Wasowski, J., Sciarra, N., Eds.; Springer International Publishing: Cham, Switzerland, 2015; pp. 1913-1917.

39. David, C.; Menéndez, B.; Darot, M. Influence of Stress-Induced and Thermal Cracking on Physical Properties and Microstructure of La Peyratte Granite. Int. J. Rock Mech. Min. Sci. Geomech. Abstr. 1999, 4, 433-448. [CrossRef]

40. Sygała, A.; Bukowska, M.; Janoszek, T. High Temperature Versus Geomechanical Parameters of Selected Rocks-The Present State of Research. J. Sustain. Min. 2013, 12, 45-51. [CrossRef]

41. Zhao, Z. Thermal Influence on Mechanical Properties of Granite: A Microcracking Perspective. Rock Mech. Rock Eng. 2016, 49, 747-762. [CrossRef]

42. Yavuz, H.; Demirdag, S.; Caran, S. Thermal Effect on the Physical Properties of Carbonate Rocks. Int. J. Rock Mech. Min. Sci. 2010, 47, 94-103. [CrossRef]

43. Hajpál, M.; Török, Á. Mineralogical and Colour Changes of Quartz Sandstones by Heat. Environ. Geol. 2004, 46, 311-322. [CrossRef]

44. Vázquez, P.; Shushakova, V.; Gómez-Heras, M. Influence of Mineralogy on Granite Decay Induced by Temperature Increase: Experimental Observations and Stress Simulation. Eng. Geol. 2015, 189, 58-67. [CrossRef]

45. Martínez-Ibáñez, V.; Benavente, D.; Hidalgo Signes, C.; Tomás, R.; Garrido, M.E. Temperature-Induced Explosive Behaviour and Thermo-Chemical Damage on Pyrite-Bearing Limestones: Causes and Mechanisms. Rock Mech. Rock Eng. 2020. [CrossRef]

46. Gautam, P.K.; Verma, A.K.; Sharma, P.; Singh, T.N. Evolution of Thermal Damage Threshold of Jalore Granite. Rock Mech. Rock Eng. 2018, 51, 2949-2956. [CrossRef]

47. Homand-Etienne, F.; Houpert, R. Thermally Induced Microcracking in Granites: Characterization and Analysis. Int. J. Rock Mech Min. Sci. Geomech. Abstr. 1989, 26, 125-134. [CrossRef]

48. Sun, Q.; Zhang, W.; Xue, L.; Zhang, Z.; Su, T. Thermal Damage Pattern and Thresholds of Granite. Environ. Earth Sci. 2015, 74, 2341-2349. [CrossRef]

49. Brotóns, V.; Tomás, R.; Ivorra, S.; Alarcón, J.C. Temperature Influence on the Physical and Mechanical Properties of a Porous Rock: San Julian's Calcarenite. Eng. Geol. 2013, 167, 117-127. [CrossRef]

50. Takarli, M.; Prince-Agbodjan, W. Temperature Effects on Physical Properties and Mechanical Behavior of Granite: Experimental Investigation of Material Damage. JAI 2008, 5, 1-13. [CrossRef]

51. Gomez-Heras, M.; Vázquez, P.; Fort, R.; Carrizo, L.; Alonso, F.J. Effects of High. Temperatures in Building Granites: MicroCracking Patterns and Ultrasound Velocity Attenuation. Geologica Balcanica 2010, 39.

52. Liu, S.; Xu, J. Mechanical Properties of Qinling Biotite Granite after High Temperature Treatment. Int. J. Rock Mech. Min. Sci. 2014, 71, 188-193. [CrossRef]

53. Liu, S.; Xu, J. An Experimental Study on the Physico-Mechanical Properties of Two Post-High-Temperature Rocks. Eng. Geol. 2015, 185, 63-70. [CrossRef]

54. Yin, T.; Shu, R.; Li, X.; Wang, P.; Liu, X. Comparison of Mechanical Properties in High Temperature and Thermal Treatment Granite. Trans. Nonferrous Met. Soc. China 2016, 26, 1926-1937. [CrossRef]

55. Kumari, W.G.P.; Ranjith, P.G.; Perera, M.S.A.; Chen, B.K.; Abdulagatov, I.M. Temperature-Dependent Mechanical Behaviour of Australian Strathbogie Granite with Different Cooling Treatments. Eng. Geol. 2017, 229, 31-44. [CrossRef]

56. Yang, S.Q.; Ranjith, P.G.; Jing, H.W.; Tian, W.L.; Ju, Y. An Experimental Investigation on Thermal Damage and Failure Mechanical Behavior of Granite after Exposure to Different High Temperature Treatments. Geothermics 2017, 65, 180-197. [CrossRef]

57. Hu, J.; Sun, Q.; Pan, X. Variation of Mechanical Properties of Granite after High-Temperature Treatment. Arab. J. Geosci. 2018, 11, 43. [CrossRef]

58. Biró, A.; Hlavička, V.; Lublóy, É. Effect of Fire-Related Temperatures on Natural Stones. Constr. Build. Mater. 2019, $212,92-101$. [CrossRef]

59. Keshavarz, M.; Pellet, F.L.; Loret, B. Damage and Changes in Mechanical Properties of a Gabbro Thermally Loaded up to $1000{ }^{\circ} \mathrm{C}$ Pure Appl. Geophys. 2010, 167, 1511-1523. [CrossRef]

60. Wu, X.; Huang, Z.; Song, H.; Zhang, S.; Cheng, Z.; Li, R.; Wen, H.; Huang, P.; Dai, X. Variations of Physical and Mechanical Properties of Heated Granite After Rapid Cooling with Liquid Nitrogen. Rock Mech. Rock Eng. 2019, 52, 2123-2139. [CrossRef]

61. Shao, S.; Wasantha, P.L.P.; Ranjith, P.G.; Chen, B.K. Effect of Cooling Rate on the Mechanical Behavior of Heated Strathbogie Granite with Different Grain Sizes. Int. J. Rock Mech. Min. Sci. 2014, 70, 381-387. [CrossRef]

62. Zhang, W.; Sun, Q.; Hao, S.; Wang, B. Experimental Study on the Thermal Damage Characteristics of Limestone and Underlying Mechanism. Rock Mech. Rock Eng. 2016, 49, 2999-3008. [CrossRef]

63. Chen, L.; Wang, C.P.; Liu, J.F.; Li, Y.; Liu, J.; Wang, J. Effects of Temperature and Stress on the Time-Dependent Behavior of Beishan Granite. Int. J. Rock Mech. Min. Sci. 2017, 93, 316-323. [CrossRef]

64. Chen, Y.-L.; Ni, J.; Shao, W.; Azzam, R. Experimental Study on the Influence of Temperature on the Mechanical Properties of Granite under Uni-Axial Compression and Fatigue Loading. Int. J. Rock Mech. Min. Sci. 2012, 56, 62-66. [CrossRef]

65. Dwivedi, R.D.; Goel, R.K.; Prasad, V.V.R.; Sinha, A. Thermo-Mechanical Properties of Indian and Other Granites. Int. J. Rock Mech. Min. Sci. 2008, 45, 303-315. [CrossRef] 
66. Mao, X.; Zhang, L.; Li, T.; Liu, H. Properties of Failure Mode and Thermal Damage for Limestone at High Temperature. Min. Sci. Technol. (China) 2009, 19, 290-294. [CrossRef]

67. Ozguven, A.; Ozcelik, Y. Effects of High Temperature on Physico-Mechanical Properties of Turkish Natural Building Stones. Eng. Geol. 2014, 183, 127-136. [CrossRef]

68. Rao, G.M.N.; Murthy, C.R. Dual Role of Microcracks: Toughening and Degradation. Can. Geotech. J. 2011. [CrossRef]

69. Sengun, N. Influence of Thermal Damage on the Physical and Mechanical Properties of Carbonate Rocks. Arab. J. Geosci. 2014, 7, 5543-5551. [CrossRef]

70. Shao, S.; Ranjith, P.G.; Wasantha, P.L.P.; Chen, B.K. Experimental and Numerical Studies on the Mechanical Behaviour of Australian Strathbogie Granite at High Temperatures: An Application to Geothermal Energy. Geothermics 2015, 54, 96-108. [CrossRef]

71. Singh, B.; Ranjith, P.G.; Chandrasekharam, D.; Viete, D.; Singh, H.K.; Lashin, A.; Al Arifi, N. Thermo-Mechanical Properties of Bundelkhand Granite near Jhansi, India. Geomech. Geophys. Geo Energ. Geo Resour. 2015, 1, 35-53. [CrossRef]

72. Török, A.; Török, Á. The Effect of Temperature on the Strength of Two Different Granites. Cent. Eur. Geol. 2015, 58, 356-369. [CrossRef]

73. Xu, X.L.; Zhang, Z.-Z. Acoustic Emission and Damage Characteristics of Granite Subjected to High Temperature. Adv. Mater. Sci. Eng. 2018, 2018, 1-12. [CrossRef]

74. Zhang, J.; Chen, X.; Kang, H. Experimental Investigation of Mechanical Properties and Energy Features of Granite after Heat Treatment under Different Loading Paths. Teh. Vjesn. 2017, 24, 1841-1851. [CrossRef]

75. Saiang, C.; Miskovsky, K. Effect of Heat on the Mechanical Properties of Selected Rock Types-A Laboratory Study. In Proceedings of the ISRM-12CONGRESS-2011-141; International Society for Rock Mechanics and Rock Engineering, Beijing, China, 1 January $2011 ;$ p. 6.

76. Zhang, F.; Zhao, J.; Hu, D.; Skoczylas, F.; Shao, J. Laboratory Investigation on Physical and Mechanical Properties of Granite after Heating and Water-Cooling Treatment. Rock Mech. Rock Eng. 2018, 51, 677-694. [CrossRef]

77. Barton, N.; Choubey, V. The Shear Strength of Rock Joints in Theory and Practice. Rock Mech. Felsmech. Mécanique Des Roches 1977. [CrossRef]

78. Khamrat, S.; Thongprapha, T.; Fuenkajorn, K. Thermal Effects on Shearing Resistance of Fractures in Tak Granite. J. Struct. Geol. 2018, 111, 64-74. [CrossRef]

79. Tang, Z.C. Experimental Investigation on Temperature-Dependent Shear Behaviors of Granite Discontinuity. Rock Mech. Rock Eng. 2020, 53, 4043-4060. [CrossRef]

80. Kim, T.; Jeon, S. Experimental Study on Shear Behavior of a Rock Discontinuity Under Various Thermal, Hydraulic and Mechanical Conditions. Rock Mech. Rock Eng. 2019, 52, 2207-2226. [CrossRef]

81. Blackwelder, E. Fire as an Agent in Rock Weathering. J. Geol. 1927, 35, 134-140. [CrossRef]

82. Dorn, R.I. Boulder Weathering and Erosion Associated with a Wildfire, Sierra Ancha Mountains, Arizona. Geomorphology 2003, 55, 155-171. [CrossRef]

83. Žabota, B.; Mikoš, M.; Kobal, M. Rockfall Modelling in Forested Areas: The Role of Digital Terrain Model. Spatial Resolution. Nat. Haz. Earth Syst. 2019. [CrossRef]

84. Moos, C.; Dorren, L.K.A.; Stoffel, M. Quantifying the Effect of Forests on Frequency and Intensity of Rockfalls. Nat. Hazards Earth Syst. Sci. 2017, 17, 291-304. [CrossRef]

85. Dupire, S.; Bourrier, F.; Monnet, J.-M.; Bigot, S.; Borgniet, L.; Berger, F.; Curt, T. The Protective Effect of Forests against Rockfalls across the French Alps: Influence of Forest Diversity. For. Ecol. Manag. 2016, 382, 269-279. [CrossRef]

86. Jonsson, M.J.O. Energy Absorption of Trees in a Rockfall Protection Forest; ETH Zurich: Zurich, Switzerland, $2007 ;$ p. 1.

87. Dorren, L.K.A.; Berger, F.; Putters, U.S. Real-Size Experiments and 3-D Simulation of Rockfall on Forested and Non-Forested Slopes. Nat. Hazards Earth Syst. Sci. 2006, 6, 145-153. [CrossRef]

88. Dorren, L.; Berger, F.; Jonsson, M.; Krautblatter, M.; Mölk, M.; Stoffel, M.; Wehrli, A. State of the Art in Rockfall-Forest Interactions. Schweiz. Z. Fur Forstwes. 2007, 158, 128-141. [CrossRef]

89. Davis, K.T.; Dobrowski, S.Z.; Higuera, P.E.; Holden, Z.A.; Veblen, T.T.; Rother, M.T.; Parks, S.A.; Sala, A.; Maneta, M.P. Wildfires and Climate Change Push Low-Elevation Forests across a Critical Climate Threshold for Tree Regeneration. Proc. Natl. Acad. Sci. USA 2019, 116, 6193-6198. [CrossRef] [PubMed]

90. Li, L.; Lan, H. Probabilistic Modeling of Rockfall Trajectories: A Review. Bull. Eng. Geol. Environ. 2015, 74, 1163-1176. [CrossRef]

91. Sabatakakis, N.; Depountis, N.; Vagenas, N. Evaluation of Rockfall Restitution Coefficients. In Engineering Geology for Society and Territory-Volume 2; Lollino, G., Giordan, D., Crosta, G.B., Corominas, J., Azzam, R., Wasowski, J., Sciarra, N., Eds.; Springer International Publishing: Cham, Switzerland, 2015; pp. 2023-2026; ISBN 978-3-319-09056-6.

92. Depountis, N.; Lainas, S.; Pyrgakis, D.; Sabatakakis, N.; Koukis, G. Engineering Geological and Geotechnical Investigation of Landslide Events in Wildfire Affected Areas of Ilia Prefecture, Western Greece. Geosociety 2017, 43, 1138. [CrossRef]

93. Wang, Y.; Jiang, W.; Cheng, S.; Song, P.; Mao, C. Effects of the Impact Angle on the Coefficient of Restitution in Rockfall Analysis Based on a Medium-Scale Laboratory Test. Nat. Hazards Earth Syst. Sci. 2018, 18, 3045-3061. [CrossRef]

94. Bar, N.; Nicoll, S.; Pothitos, F. Rock Fall Trajectory Field Testing, Model Simulations and Considerations for Steep Slope Design in Hard Rock. In Proceedings of the First Asia Pacific Slope Stability in Mining Conference, Brisbane, Australia, 6-8 September 2016; pp. 457-466. 
95. Zavala, L.M.; De Celis, R.; Jordán, A. How Wildfires Affect Soil Properties. A Brief Review. Cuad. De Investig. Geográfica 2014, 40, 311. [CrossRef]

96. Lopez-Saez, J.; Corona, C.; Eckert, N.; Stoffel, M.; Bourrier, F.; Berger, F. Impacts of Land-Use and Land-Cover Changes on Rockfall Propagation: Insights from the Grenoble Conurbation. Sci. Total Environ. 2016, 547, 345-355. [CrossRef] [PubMed]

97. Jancke, O.; Berger, F.; Dorren, L.K.A. Mechanical Resistance of Coppice Stems Derived from Full-Scale Impact Tests. Earth Surf. Process. Landf. 2013, 38, 994-1003. [CrossRef]

98. U.S. Fire Administration Firefighters Fatalities Report. Available online: https://apps.usfa.fema.gov/firefighter-fatalities/ fatalityData/reportBuilder (accessed on 25 February 2021).

99. Ministerio de Agricultura, Pesca y Alimentación. Fallecidos En Incendios Forestales En España 1991-2015; Ministerio de Agricultura, Pesca y Alimentación: Madrid, Spain, 2016.

100. Gobierno de Aragón. Manual de Formación de Incendios Forestales Para Cuadrillas; Government of Aragon: Zaragoza, Spain, 2001.

101. Junta de Extremadura. Manual Básico Del Bombero Forestal En Extremadura; Consejería de Agricultura, Desarrollo Rural, Población y Territorio: Mérida, Spain, 2019.

102. Ministerio de Agricultura, Alimentación y Medio. Ambiente Trabajos Bajo Desprendimientos de Rocas En Horario Cercano a La Puesta de Sol. Comité de Lucha Contra Incendios Forestales; Lecciones Aprendidas: Madrid, Spain, 2021.

103. Yu, Z.X.; Zhao, L.; Liu, Y.P.; Zhao, S.C.; Xu, H.; Chan, S.L. Studies on Flexible Rockfall Barriers for Failure Modes, Mechanisms and Design Strategies: A Case Study of Western China. Landslides 2019, 16, 347-362. [CrossRef]

104. Franklin, J.A. RHRON: Ontario Rockfall Hazard. Rating System: Field Procedures Manual; Engineering Standards Branch, Ontario Ministry of Transportation: Downsview, ON, Canada, 2012; ISBN 978-1-4435-9147-8.

105. Bourrier, F.; Hungr, O. Rockfall Dynamics: A Critical Review of Collision and Rebound Models. In Rockfall Engineering; John Wiley \& Sons, Ltd.: Hoboken, NJ, USA, 2013; pp. 175-209; ISBN 978-1-118-60153-2.

106. Robles, J.M.; Peña, Á.; Pinto, H. Dynamic Barriers for Protection against Rocks Falls. Rev. De La Construcción. J. Constr. 2016, 15, 27-37. [CrossRef]

107. Vagnon, F.; Bonetto, S.; Ferrero, A.M.; Harrison, J.P.; Umili, G. Eurocode 7 and Rock Engineering Design: The Case of Rockfall Protection Barriers. Geosciences 2020, 10, 305. [CrossRef]

108. Grimod, A.; Giacchetti, G. Design Approach for Rockfall Barriers Tested According to ETAG 027. In Proceedings of the Landslide Science for a Safer Geoenvironment; Sassa, K., Canuti, P., Yin, Y., Eds.; Springer International Publishing: Cham, Switzerland, 2014; pp. 91-97.

109. New Zealand Geotechnical Society Rockfall: Design Considerations for Passive Protection Structures; New Zealand Geothenical Society: Wellington, New Zealand, 2016; ISBN 978-0-947497-62-0.

110. Vessely, M.; Richrath, S.; Weldemicael, E. Economic Impacts from Geologic Hazard Events on Colorado Department of Transportation Right-of-Way. Transp. Res. Rec. 2017, 2646, 8-16. [CrossRef]

111. Kjekstad, O.; Highland, L. Economic and Social Impacts of Landslides. In Landslides-Disaster Risk Reduction; Sassa, K., Canuti, P., Eds.; Springer Berlin Heidelberg: Berlin/Heidelberg, Germany, 2009; pp. 573-587; ISBN 978-3-540-69966-8.

112. UVR Ertzaintza Laida Beach Wildfire Located in the Urdaibai Biosphere Reserve (UNESCO). Available online: https://twitter. com/UvrErtzaintza/status/1246832668907634693 (accessed on 25 February 2021).

113. IGME Geological Map of Spain. Sheet 261 (4-12): Tuy. Magna 50k (2nd Ser.). 1981. Available online: http://info.igme.es/ cartografiadigital/geologica/Magna50.aspx?language=en (accessed on 1 March 2021).

114. Twidale, C.; Vidal-Romaní, J. Landforms and Geology of Granite Terrains; CRC Press (Taylor and Francis Group): Cleveland, OH, USA, 2005; ISBN 9780415364355.

115. Pérez-Rey, I.; Riquelme, A.; González-deSantos, L.M.; Estévez-Ventosa, X.; Tomás, R.; Alejano, L.R. A Multi-Approach Rockfall Hazard Assessment on a Weathered Granite Natural Rock Slope. Landslides 2019, 16, 2005-2015. [CrossRef]

116. Rocscience RocFall 6.0 2016. Available online: https://www.rocscience.com/documents/pdfs/rocnews/2016fall/rocfall_v6 _beta_release.pdf (accessed on 1 March 2021).

117. Riquelme, A.; Abellán, A.; Tomás, R.; Jaboyedoff, M. A New Approach for Semi-Automatic Rock Mass Joints Recognition from 3D Point Clouds. Comput. Geosci. 2014, 68, 38-52. [CrossRef]

118. Riquelme, A.; Abellán, A.; Tomás, R.; Jaboyedoff, M. Discontinuity Set Extractor. 2014. Available online: https:/ / personal.ua.es / en/ariquelme/discontinuity-set-extractor-software.html (accessed on 1 March 2021).

119. Palmstrom, A. Measurements of and Correlations between Block Size and Rock Quality Designation (RQD). Tunn. Undergr. Space Technol. 2005, 20, 362-377. [CrossRef]

120. Mölk, M.; Poisel, R.; Weilbold, J.; Angerer, H. Rockfall Rating Systems: Is There a Comprehensive Method for Hazard Zoning in Populated Areas? In Proceedings of the 11th Interpraevent Congress; International Research Society Interpraevent: Dornbirn, Austria, 2008; pp. 207-218.

121. Alejano, L.R.; Pons, B.; Bastante, F.G.; Alonso, E.; Stockhausen, H.W. Slope Geometry Design as a Means for Controlling Rockfalls in Quarries. Int. J. Rock Mech. Min. Sci. 2007, 44, 903-921. [CrossRef]

122. Alejano Monge, L.R.; García Cortés, S.; García-Bastante, F.; Martínez Alegría, R. Study of a Rockfall in a Limy Conglomerate Canyon (Covarrubias, Burgos, N. Spain). Environ. Earth Sci. 2013. [CrossRef]

123. Pierson, L.A.; Davis, S.A.; Van Vickle, R. Rockfall Hazard Rating System: Implementation Manual; Federal Highway Administration: Washington, DC, USA, 1990. 
124. Alejano, L.R.; Stockhausen, H.W.; Alonso, E.; Bastante, F.G.; Ramírez Oyanguren, P. ROFRAQ: A Statistics-Based Empirical Method for Assessing Accident Risk from Rockfalls in Quarries. Int. J. Rock Mech. Min. Sci. 2008, 45, 1252-1272. [CrossRef]

125. Mateos, R.M.; Ezquerro, P.; Azañón, J.M.; Gelabert, B.; Herrera, G.; Fernández-Merodo, J.A.; Spizzichino, D.; Sarro, R.; García-Moreno, I.; Béjar-Pizarro, M. Coastal Lateral Spreading in the World Heritage Site of the Tramuntana Range (Majorca, Spain). The Use of PSInSAR Monitoring to Identify Vulnerability. Landslides 2018, 1-13. [CrossRef]

126. Mateos, R.M. Freeze-Thaw Cycles and Rainfall as Triggering Factors of Mass Movements in a Warm Mediterranean Region: The Case of the Tramuntana Range (Majorca, Spain). Landslides 2012. [CrossRef]

127. Barrera Morate, J.L.; García Moral, R. Mapa Geológico de Canarias; GRAFCAN: Santa Cruz de Tenerife, Spain, 2011.

128. Cabildo de Tenerife Plan Territorial Parcial de Ordenación Comarca Ycoden-Daute-Isla Baja. Available online: https://www. tenerife.es/planes/PTPOYcodenDauteIslaBaja/PTPOYcodenindex.htm (accessed on 1 March 2021).

129. Copernicus Emergency Management Service. EMSR379: Forest Fire in Artenara, Spain EMSR381: Forest Fire InCazadores, Spain EMSR382: Forest Fire in Valleseco, Gran Canaria, Spain-Information Bulletin 120. 2019. Available online: https:// www.copernicus.eu/en/news/news/emsr379-forest-fire-artenara-spain-emsr381-forest-fire-cazadores-spain-emsr382-forest (accessed on 1 March 2021).

130. Wieczorek, G.F.; Guzzetti, F. A Review of Rainfall Thresholds Tor Triggering Landslides. In Mediterranean Storms 1999-Proceedings EGS Plinius Conference, Maratea, Italy, October 1999; Editoriale Bios: Consenza, Italy, 2000.

131. Ansari, M.K.; Ahmed, M.; Rajesh Singh, T.N.; Ghalayani, I. Rainfall, A Major Cause for Rockfall Hazard along the Roadways, Highways and Railways on Hilly Terrains in India. In Proceedings of the Engineering Geology for Society and Territory-Volume 1; Lollino, G., Manconi, A., Clague, J., Shan, W., Chiarle, M., Eds.; Springer International Publishing: Cham, Switzerland, 2015; pp. $457-460$.

132. Collins, B.D.; Stock, G.M. Rockfall Triggering by Cyclic Thermal Stressing of Exfoliation Fractures. Nat. Geosci. 2016, 9, 395-400 [CrossRef]

133. Saroglou, C. GIS-Based Rockfall Susceptibility Zoning in Greece. Geosciences 2019, 9, 163. [CrossRef]

134. Rossi, M.; Sarro, R.; Reichenbach, P.; Mateos, R.M. Probabilistic Identification of Rockfall Source Areas at Regional Scale in El Hierro (Canary Islands, Spain). Geomorphology 2021, 381, 107661. [CrossRef] 